University of Nebraska - Lincoln

DigitalCommons@University of Nebraska - Lincoln

July 2008

\title{
How management style moderates the relationship between abusive supervision and workplace deviance: An uncertainty management theory perspective
}

\author{
Stefan Thau \\ London Business School, Regent's Park, London NW1 4SA, UK \\ Rebecca J. Bennett \\ Louisiana Tech University, USA \\ Marie S. Mitchell \\ University of Nebraska - Lincoln, mmitchell3@unl.edu \\ Mary Beth Marrs \\ College of Business, University of Missouri, USA
}

Follow this and additional works at: https://digitalcommons.unl.edu/managementfacpub

Part of the Management Sciences and Quantitative Methods Commons

Thau, Stefan; Bennett, Rebecca J.; Mitchell, Marie S.; and Marrs, Mary Beth, "How management style moderates the relationship between abusive supervision and workplace deviance: An uncertainty management theory perspective" (2008). Management Department Faculty Publications. 2.

https://digitalcommons.unl.edu/managementfacpub/2

This Article is brought to you for free and open access by the Management Department at DigitalCommons@University of Nebraska - Lincoln. It has been accepted for inclusion in Management Department Faculty Publications by an authorized administrator of DigitalCommons@University of Nebraska - Lincoln. 
Published in Organizational Behavior and Human Decision Processes (2008); doi 10.1016/j.obhdp.2008.06.003

Copyright $\odot 2008$ Elsevier Inc. Used by permission.

http://www.sciencedirect.com/science/journal/07495978

Submitted November 12, 2006; accepted June 4, 2008; published online July 16, 2008.

\title{
How management style moderates the relationship between abusive supervision and workplace deviance: An uncertainty management theory perspective
}

\author{
Stefan Thau, ${ }^{*}$ Rebecca J. Bennett, ${ }^{\dagger}$ Marie S. Mitchell, ${ }^{\ddagger}$ and Mary Beth Marrs ${ }^{\S}$ \\ * Organizational Behaviour Subject Area, London Business School, Regent's Park, London NW1 4SA, UK (corresponding author) \\ ${ }^{\dagger}$ Department of Management and Information Systems, Louisiana Tech University, USA \\ ‡ Department of Management, University of Nebraska-Lincoln, USA \\ $\S$ College of Business, University of Missouri, USA
}

\begin{abstract}
Based on uncertainty management theory [Lind, E. A., \& Van den Bos, K., (2002). When fairness works: Toward a general theory of uncertainty management. In Staw, B. M., \& Kramer, R. M. (Eds.), Research in organizational behavior (Vol. 24, pp. 181-223). Greenwich, CT: JAI Press.], two studies tested whether a management style depicting situational uncertainty moderates the relationship between abusive supervision and workplace deviance. Study 1, using survey data from 379 subordinates of various industries, found that the positive relationship between abusive supervision and organizational deviance was stronger when authoritarian management style was low (high situational uncertainty) rather than high (low situational uncertainty). No significant interaction effect was found on interpersonal deviance. Study 2, using survey data from 1477 subordinates of various industries, found that the positive relationship between abusive supervision and supervisor-directed and organizational deviance was stronger when employees' perceptions of their organization's management style reflected high rather than low situational uncertainty.
\end{abstract}

Keywords: abusive supervision, workplace deviance, uncertainty management theory, authoritarian management style, uncertainty perceptions, management style

There is ample empirical evidence to suggest that employees respond quite negatively to supervisor mistreatment by engaging in behaviors that are harmful to the organization and to its members (e.g., Ambrose et al., 2002; Aquino et al., 2001; Bies and Tripp, 1998a; Mitchell and Ambrose, 2007; Skarlicki and Folger, 1997). An often-invoked explanation for these findings is social exchange theory (see Cropanzano \& Mitchell, 2005 for a review). According to this theory, in an interdependent workplace relationship, poor treatment by one's supervisor indicates an imbalance that subordinates seek to rectify by engaging in negative behaviors themselves. The norm of reciprocity (Gouldner, 1960) guides this quid pro quo behavior; employees abused by their supervisors reciprocate mistreatment back to the organization and to its agent, the supervisor.

Although social exchange-based models have found good support in the management literature (Cropanzano \& Mitchell, 2005), they have been challenged to consider why and when poor treatment matters to employees. Various writers have noted that the boundary effects of fairness-related information, which influences employees' reactions, are poorly established (Ambrose and Schminke, 2003; Colquitt and Greenberg, 2003; Cropanzano et al., 2001; Lind and Van den Bos, 2002; Thau et al., 2007). Some theoretical reviews (Colquitt and Greenberg, 2003; Cropanzano et al.,
2001) suggest that assessing the situational context in which injustice occurs can help build a better understanding of when and why retaliatory reactions are less likely. However, empirical research exploring situational factors that make mistreatment more or less salient to those receiving it is scarce and lacks a clear theoretical foundation (see Tepper, 2007, for a review). The theory we apply in this paper assumes that the salience of supervisory mistreatment is influenced by the amount of uncertainty in employees' work environment (Ambrose and Schminke, 2003; Lind and Van den Bos, 2002).

The starting point of our model is that employees encounter various uncertainties in organizations that can be quite tenuous (e.g., Hogan, 1983; Hogg and Mullin, 1999) that need to be cognitively managed or made tolerable (Lind \& Van den Bos, 2002). Uncertainty management theory (UMT) argues that fairness-related information provides employees with the means to manage uncertainties (Lind and Van den Bos, 2002; Van den Bos and Lind, 2002, for reviews). Thus, fairness concerns become more salient to employees when they experience uncertainty. This explains why supervisor mistreatment combined with high levels of uncertainty results in stronger negative reactions from employees than mistreatment combined with low levels of uncertainty (Tangirala and Alge, 2006; Thau et al., 2007). 
In this paper, we argue that the extent to which management's actions and decisions - which we refer to as "management style" depict uncertainty will impact the relationship between employees' perceptions of supervisor mistreatment and their engagement in workplace deviance. In Study 1, we examine the relationships between abusive supervision (Tepper, 2000) and organizational and interpersonal deviance (Bennett \& Robinson, 2000), and the moderating effects of authoritarian management style (Heaven, 1985). Authoritarian management style, which is rigid, dogmatic, and rule-bound, is generally associated with predictable managerial behaviors (Altemeyer, 1988). We believe employees who perceive their organization's management style to be highly authoritarian will experience little uncertainty and so the quality of interpersonal treatment (such as abusive treatment) becomes less salient to them, making the impact of abuse on deviance less strong. Those who do not perceive their organization's management style to be authoritarian will react more strongly and negatively (via deviance) to an abusive supervisor.

In Study 2, we provide a more rigorous test of the influence of abused employees' perceptions of uncertainty regarding management style. Specifically, we examine the relationship between abusive supervision and supervisor-directed and organizational deviance and the moderating effects of perceptions of uncertainty about management's actions and decisions. Based on a review of the uncertainty literature across disciplines (e.g., Afifi and Burgoon, 2000; Knight, 1921; March, 1978; Marris, 1993; Mazursky and Ofir, 1990; Pitz and Sachs, 1984; Taleb, 2007; Wilson et al., 2005), we define perceived uncertainty of management style as perceptions of management's actions and decisions as being (un)predictable, (not) surprising, and (un)expected.

We believe our studies contribute to a better understanding of the boundary conditions of fair treatment effects, specifically of conditions limiting/escalating the effects of abusive supervision on deviance. We also provide a test of the generalizability of UMT - previous tests of UMT are mostly experimental and investigate affective and attitudinal reactions to uncertainty (Lind and Van den Bos, 2002; Tangirala and Alge, 2006). Moreover, applications of UMT to explain harmful employee behaviors are scarce and have been limited to investigations of self-concept uncertainty (Colquitt et al., 2006; Thau et al., 2007). We extend this literature by investigating the moderating effect of situational sources of uncertainty.

Deviant behaviors can have different targets (e.g., coworkers, organizations, authorities; Ambrose et al., 2002; Bennett and Robinson, 2003; Mitchell \& Ambrose, 2007) and both social exchange based theory (Cropanzano \& Mitchell, 2005) and data suggest that employees engage in deviance that targets the source of the abuse (Berry et al., 2007; Hershcovis et al., 2007). In contrast, UMT and its application in organizational behavior (e.g., Colquitt et al., 2006; Thau et al., 2007) does not specify whether the increased attention paid to fairness criteria (e.g., supervisor abuse) which is prompted by uncertainty has a differential impact on targets of the resulting deviant behavior. In the current paper, we integrate insights from the target perspective (of social exchange theory) and test the strength of the moderating effects of uncertainty perceptions (from UMT) on the relationship of abusive supervision and the different forms of deviance.

\section{Abusive supervision and workplace deviance}

People pay attention to the interpersonal treatment they receive from organizational authorities (Lind \& Tyler, 1988). Fair and respectful treatment conveys to employees that they are respected and valued (Lind and Tyler, 1988; Tyler, 1999; Tyler and Lind, 1992) and that their position in the organization is secure (Van den Bos, Lind, \& Wilke, 2001). Fairness heuristic theory (Tyler \& Lind,
1992) argues that once fairness judgments have been formed, people use these judgments to decide how to behave; if supervisors are perceived as fair, employees will react favorably and will acquiesce to demands or requests with little concern for material outcomes. The group engagement model (Tyler \& Blader, 2003) suggests that this is particularly true for discretionary behaviors; employees who feel respected by their supervisors become highly committed to the work group and become motivated to help the group. Social exchange theory makes a similar argument in its proposition that individuals reciprocate the positive regard they receive from the organization and its members and, consequently, engage in organizational citizenship behaviors (OCBs) and other manifestations of organizational commitment (Masterson, Lewis, Goldman, \& Taylor, 2000).

In contrast, authorities who violate standards of respectful interpersonal treatment abate employees' perceptions of fair treatment (Bies, 2001; Bies and Moag, 1986; Skarlicki and Folger, 1997; Tepper, 2000), and promote negative reactions (see Tepper, 2007 for a review). Abusive supervision denotes employees' perceptions of the persistent verbal and non-verbal abuse by supervisors (Tepper, 2000). Abusive supervisors use their power to oppress and brutalize employees (Ashforth, 1997). They yell and scream, intimidate, ridicule, and humiliate their employees (Keashly, 1998; Mitchell and Ambrose, 2007). Therefore, abusive supervision represents employees' perceptions of what they believe are purposeful and unfair supervisor mistreatment (Tepper, 2007).

Based on social exchange principles (Blau, 1964), supervisory mistreatment promotes retaliatory behavior (Mitchell and Ambrose, 2007; Skarlicki and Folger, 1997). Employees who are abused by their supervisors seek to get back at or to make their harm doer pay in some way (Skarlicki \& Folger, 2004). Indeed, research supports these contentions. Employees who perceive that their supervisors interpersonally mistreat them are more likely to resist their supervisors' influence tactics (Tepper, Duffy, \& Shaw, 2001), withhold beneficial work behaviors (e.g., organizational citizenship behavior [OCB], Zellars, Tepper, \& Duffy, 2002, performance, Harris, Kacmar, \& Zivnuska, 2007), and engage in deviant behavior targeted toward the supervisor (Baron et al., 1999; Innes et al., 2005) and the organization (Aquino et al., 1999; Detert et al., 2007).

While this research supports the social exchange view that employees who are abused by their supervisors reciprocate mistreatment by engaging in workplace deviance, we also know that not all employees retaliate or engage in deviance (Bies and Tripp, 1998b; Keashly et al., 1994; Keashly et al., 1994; Tepper et al., 2001). Based on qualitative research, Bies and Tripp (1998a, 1998b) found that one reason why some employees engage in retaliation while others do not was their work environment. That is, some organizational environments fuel while others quell employees' destructive behavior. Research has yet to explore situational factors that influence employees' reactions to supervisor abuse (see Tepper, 2007 for a review). As a consequence, we know very little about the boundary conditions that magnify or minimize such retaliatory effects.

An emerging theoretical perspective based on UMT principles argues that workplace uncertainty influences the relationship between supervisory treatment and employees' behaviors (Lind and Van den Bos, 2002; Tangirala and Alge, 2006). This research shows supervisor mistreatment becomes more salient to employees when work environments are uncertain (Lind and Van den Bos, 2002; Van den Bos and Lind, 2002). Social exchange research has found that social exchanges are highly influenced by perceptions of uncertainty (Molm \& Cook, 1995). Thus, we believe perceptions of uncertainty in employees' work environment may affect the relationship between abusive supervision and workplace deviance. Uncertainty management theory (UMT) guides our thinking, which we explain below. 


\section{Uncertainty management theory}

According to UMT, one of people's biggest challenges in life is to cope with the various uncertainties they experience in social relationships (Lind and Van den Bos, 2002; Van den Bos and Lind, 2002). The need for predictability and uncertainty reduction arguably has an evolutionary basis (Hogan, 1983; Stevens and Fiske, 1995). Uncertainty is an aversive and alarming experience (Van den Bos et al., 2008), making people worry about the control they have in their life and the quality of the outcomes they could receive (Lind and Van den Bos, 2002; Tangirala and Alge, 2006). Uncertainty affects people's cognitions, perceptions, feelings, and behaviors (Van den Bos \& Lind, 2002). Because uncertainty threatens one's general sense of self (Hogg, 2001), people try to find some way to tolerate it or to make it more cognitively manageable (Van den Bos \& Lind, 2002). Within a work context, employees respond to uncertainty with information in their broader work environment to help them cope with it (Ashford and Cummings, 1983; Ashford and Cummings, 1985). UMT suggests that fairness-related information in the work environment provides a means by which to cope with uncertainty (Lind \& Van den Bos, 2002). When environmental uncertainty is high, employees pay more attention to fairness-related information, such as the treatment they receive from authorities (Tangirala \& Alge, 2006).

Research provides preliminary support for the idea that under conditions of high uncertainty, injustice information becomes more salient and hence has a stronger impact on negative behavioral outcomes. For example, procedural justice has a stronger impact on wrongful litigation claims at the time of termination-a time of great uncertainty - than during employment (Lind, Greenberg, Scott, \& Welchans, 2000). Another study found that interactional justice perceptions predict antisocial work behaviors only when employees' self-concepts were defined by high (but not by low) levels of uncertainty (Thau et al., 2007). Lastly, Tangirala and Alge (2006) found that fairness from authorities was more salient to employees when uncertainty was high, and that employees reacted more negatively to unfair events under high rather than low uncertainty. Research exploring the UMT predictions, however, has not specifically investigated employees' deviant reactions to supervisor mistreatment.

In the current paper, we posit that perceptions about how management generally acts and makes decisions within the organization (i.e., "management style") depict varying levels of uncertainty. UMT suggests that uncertainty perceptions make the treatment employees receive from their supervisor more salient (Lind and Van den Bos, 2002; Van den Bos and Lind, 2002). Thus, we believe that when uncertainty of the organization's general management style is high rather than low, employees' perceptions about supervisory treatment become more evident.

UMT explains that when uncertainty is coupled with unfair treatment (like abusive supervision), employees respond negatively against the organization (Van den Bos, 2001; Van den Bos and Miedema, 2000). When employees experience an abusive supervisor and an uncertain work environment, UMT suggests that employees react negatively because doing so allows them take personal control of the situation. Lind and Van den Bos (2002) state that unfair treatment becomes particularly threatening in the face of great uncertainty and drives people to act against the organization because "harming the organization is as much as a goal as protecting the self" (p. 196).

In sum, theory and empirical studies provide the basis to predict that the relationship between abusive supervision and workplace deviance will be stronger when employees perceive the management style of their organization as signaling high rather than low levels of uncertainty.
Study 1: Abusive supervision, workplace deviance, and the moderating effects of authoritarian management style

According to theory (Adorno et al., 1950; Altemeyer, 1988; Feldman, 2003) and research (Hodson and Sorrentino, 1999; Jost et al., 2003), authoritarians are characterized by a strong desire to avoid uncertainty. Authoritarians' preference for social conformity over personal autonomy reflects their predisposition toward a structured, stable, and predictable social order (Feldman, 2003). Consequently, they resist new or ambiguous experiences (Hodson and Sorrentino, 1999; McAllister and Anderson, 1991), and as a result, they are less willing to change work habits and are disinterested in work innovation (Fay \& Frese, 2000). It is not surprising, therefore, that a recent meta-analysis (Jost et al., 2003; Jost et al., 2003) suggests that people who are "politically conservative" (e.g., people who score high in authoritarianism, conservatism, or social dominance orientation) are dogmatic, cognitively inflexible, and uncertainty avoidant. Moreover, they have a high need for order and structure, advocating such diverse measures as comprehensive drug testing, core educational curricula, and quarantines for AIDS patients (Peterson, Doty, \& Winter, 1993).

Whereas authoritarianism is typically considered an individual characteristic, theorists argue it can also be understood as a perception of the work environment (Duckitt, 1989; Duckitt, 1992; Feldman, 2003; Stellmacher and Petzel, 2005). This is consistent with initial conceptualizations of authoritarianism that focused on norms and patterns within societies (Fromm, 1945) and with organizational researchers who have previously described management styles as authoritarian (e.g., Dixon et al., 2007; Janssens et al., 1995; McGregor, 1960). Our arguments are also consistent with the general logic in the management style literature. For example an "entrepreneurial management style" is assumed to result from management's general propensity to take risks, to innovate, and to compete (Covin \& Slevin, 1988). Similarly, we assume that organizations whose authorities generally have a preference for avoiding uncertainty create behavioral patterns that result in an authoritarian management style. The literature conceptualizes authoritarian management style as employees' perceptions of their organization's management's actions and decisions as rigid, dogmatic, and rule-bound (e.g., Duckitt, 1989; Duckitt, 1992; Feldman, 2003; Stellmacher and Petzel, 2005). Ergo, organizations whose management style is authoritarian make decisions and act in ways that are predictable.

Consistent with social exchange arguments (Mitchell and Ambrose, 2007; Skarlicki and Folger, 1997), we argue that employees who are abused by their supervisor will be will more likely to engage in deviant behaviors. Based on UMT predictions, we expect this relationship to be stronger when employees work under non-authoritarian management styles. Authoritarians are rigid, inflexible and follow rules explicitly. Such behavior creates situations of low uncertainty. If managers generally display authoritarian behaviors, employees will experience less uncertainty because their organization's managers demonstrate patterned and predictable behaviors in the work environment. Conversely, if the management style in the organization is more flexible and less rule-bound, there will be more uncertainty in the work environment. Applying UMT, then, employees' perceptions of abuse will be less salient when they work under a management style characterized by high levels of authoritarianism; their perceptions of abuse will be more salient when they work under an management style characterized by low levels of authoritarianism. Respectively, the retaliation effect on deviant behaviors will be stronger and weaker.

There is indirect evidence in the organizational behavior literature that supports our view that organizational situations which 
are rigid will influence the relationship between violations of considerate treatment and employee responses. For example, Ambrose and Schminke (2003) predicted and found that interactional justice has a stronger and more positive influence on supervisory trust in organic than in mechanistic organizational structures. Although this relationship was explained via a social exchange-based framework (Leventhal, 1980), the findings are also in line with UMT. Arguably, mechanistic organization structures are characterized by lower levels of situational uncertainty than organic organization structures because mechanistic organization's managerial style follows rigid, bureaucratic rules (Burns \& Stalker, 1961). Together, this suggests:

\section{Hypothesis 1 - Authoritarian management style will moder- ate the positive relationship between abusive supervision and (a) organizational deviance and (b) interpersonal deviance such that the relationships will be stronger when authoritarian manage- ment style is low rather than high.}

Workplace deviance theory (Bies and Tripp, 1997; Bies and Tripp, 1998a; Robinson and Bennett, 1997; Skarlicki and Folger, 2004) and research (Aquino and Douglas, 2003; Hershcovis et al., 2007; Mitchell and Ambrose, 2007) suggests that individuals tend to target the source of perceived transgressions, and these arguments are consistent with retaliatory principles of social exchange theory (Gouldner, 1960). For example, Robinson and Bennett (1997) argue that if the organization is the cause of the mistreatment, then deviance will most likely be directed against the organization; if an individual is the cause of the mistreatment, then deviance will be mostly likely directed against the individual.

We predict that organizational deviance is the more relevant form of deviance when employees experience supervisor abuse and we expect that the interactive effect between abusive supervision and authoritarian management style will be stronger on organizational rather than on interpersonal deviance. This is because interpersonal deviance denotes deviant behaviors generally harmful to all individuals within the organization - the target in interpersonal deviance is unspecified and can include all members of the organization, including coworkers and other parties that were not involved in the supervisor abuse. Organizational deviance, in contrast, refers to deviant behaviors directly harmful to the organization (Bennett \& Robinson, 2000). Organizational authorities are often described as agents of organizations' interests (Eisenberger et al., 2002; Levinson, 1965; Weber, 1947); hence, the interests of authorities and those of the organization should strongly overlap. This suggests that employees abused by their supervisor may retaliate by engaging in behaviors that harm the organization.

Skarlicki and Folger (1997) have made similar arguments. They integrated principles of social exchange in suggesting employees seek to retaliate for perceived mistreatment and unfair acts. Retaliation is a form of workplace deviance that encompasses behavior that seeks to get back at or to make the transgressor pay (Skarlicki \& Folger, 2004). Skarlicki and Folger (1997) contend that supervisors act as organizational agents because they take on responsibility for making decisions that impact employees' outcomes and work life. In this way, unfair supervisory treatment promotes organizational retaliation, as employees hold their organization accountable for its agents' actions and target their deviant behaviors accordingly (Skarlicki \& Folger, 2004).

Based on these principles of retaliation, we predict employees are more likely to respond to abusive behavior from an organizational agent by engaging in deviant behaviors that are directed at the source of mistreatment (organizational deviance) rather than in the more generalized interpersonal deviance. As we explained earlier, UMT does not make specific hypotheses about different targets of retaliation. Rather UMT predicts that uncertainty makes unfairness more salient. Once the unfairness is salient, social exchange theory predicts individuals will retaliate directly against the source of the injustice. Consequently, we expect high situational uncertainty to strengthen the social exchange theory predicted effects. We believe that the interactive effect of abusive supervision and authoritarian management style should be weaker on the general forms of interpersonal deviance as compared to organizational deviance. We predict:

Hypothesis 2 - The interactive effect between abusive supervision and authoritarian management style will be stronger for organizational than for interpersonal deviance.

\section{Study 1 method}

\section{Participants and procedure}

We drew a random sample of 1200 graduates of a large Midwestern university for the years 1988-1998 to ensure that a wide variety of industries, geographic locations, ages, etc. were represented. Thirty-seven subjects were eliminated from the sample as they resided outside of the United States where the workplace may differ significantly from that in the United States. The resulting 1163 subjects were mailed a survey with a cover letter encouraging participation by ensuring confidentiality of responses and offering the chance for participants to be entered into a prize drawing and to receive a summary of the study results. Reminder postcards were sent out one week later and replacement surveys were sent to nonrespondents after five weeks. Eighty-six surveys were returned by the Postal Service due to incorrect addresses. The response rate was $53.7 \%(n=578)$. Respondents who were not employed or who had been with their current employer less than four months were eliminated from the sample reducing it to 439 . Due to missing data, the final sample for hypotheses tests was 377 .

\section{Measures}

\section{Abusive supervision}

The 19 items of this scale were derived from Baron and Neuman (1996) verbal aggression scale and Tepper's (2000) abusive supervision scale. Respondents used a five-point scale $(1=$ never, $5=$ very often $)$ to indicate the frequency with which a supervisor or manager performs behaviors such as "holds a person or his/her work up to public ridicule," or "directly refuses requests." Item scores were averaged $(a=.94)$.

\section{Authoritarian management style}

We adapted Heaven's (1985) measure of authoritarian management style. The original measure reflects employees' perceptions of their immediate supervisor only. This study, however, seeks to examine employees' perceptions of the general management style within the organization. Therefore, the wording of the items was modified to measure the level of authoritarian management of the organization rather than just one authority figure. ${ }^{1}$ Subjects were

${ }^{1}$ The original measure by Heaven (1985) was developed to assess employees' perceptions of their immediate supervisor's management style. We adapted the language in the measure to assess employees overall perceptions of how managers in their organization act more generally. We believe doing so more adequately captures employees' general perceptions of patterned behaviors from authorities that are authoritarian in their organization. Modifying the measure from the source of the immediate supervisor to the organization's overall management behavioral pattern is consistent with previous research that has investigated perceptions of overall behaviors in organizations (e.g., perceived aggression in the organization, Aquino \& Douglas, 2003; entrepreneurial style, Covin \& Slevin, 1988) 
asked to respond on a seven-point Likert scale $(1=$ strongly disagree, $7=$ strongly agree) to items concerning the management of their organization. Items were: "Management is domineering in the sense of trying to impose their will on others," "Management is rigid/dogmatic in the sense that they see things as either right or wrong; there is hardly ever an in between position," Management has a difficult time seeing another's point of view," "Management is conservative in the sense of preferring 'rightist' rather than 'leftist' political parties," Management tends to be conventional in custom, manner, or dress (e.g., a male opening a door for a female; a female waiting for a male to take the initiative in a crisis)," and "Management is conservative in the sense of liking what is traditional." Item were averaged $(a=.80)$.

\section{Workplace deviance ${ }^{2}$}

We assessed organizational deviance with eleven items from Bennett and Robinson's (2000) organizational deviance scale. Sample items are: "Worked on a personal matter instead of work for your employer," "Told someone about the lousy place where you work," and "Littered your work environment." We measured interpersonal deviance with six items from Bennett and Robinson's (2000) interpersonal deviance measure. Sample items are: "Made fun of someone at work," "Made an ethnic, religious, or racial remark at work," and "Deliberately embarrassed someone at work." For both measures, respondents provided their answers on a seven-point Likert-like scale $(1=$ never, $7=$ daily $)$. Item were averaged (organizational deviance, $a=.68$; interpersonal deviance $a=.76)$.

\section{Control variables}

We controlled for several variables that may affect the relationship among our study variables but that were not of direct theoretical interest. We controlled for demographic variables such as employee age (in years), employee tenure (in months) and employee gender $(0=$ male, $1=$ female), as previous research (Aquino \& Douglas, 2003) suggests that these status variables affect employee responses to interpersonal mistreatment. We also controlled for employees' trait negative affectivity because it may be that employees with a dispositional tendency for negative affect may experience more abusive supervision and may be more likely to engage in deviant behaviors (Aquino et al., 1999; Tepper et al., 2001). This scale was measured with ten items $(1=$ very slightly or not at all, $5=$ extremely) of the positive and negative affect scale (Watson, Clark, \& Tellegen, 1988). Responses were averaged $(a=.83)$. Finally, we controlled for the possibility that authoritarian management style represents expectations of punishment for retaliation. To assess this expectation, we adapted three items based on previous research (Bingham \& Scherer, 1993) which capture the permissiveness towards aggression within the organization. These items were $(1$ = strongly disagree, 7 = strongly agree): "Verbally aggressive behavior is clearly discouraged by my superiors and co-workers (reverse coded)," "The general attitude toward communication in my organization actually encourages verbal aggression," and "To move up in management, one must behave in an aggressive manner with subordinates." Items were averaged to form a scale $(a=.76)$.

${ }^{2}$ The measures of deviance used in this study assess harmful behavior that is directed at a party, rather than specifically assessing targeted behavior that harms the party (Ambrose et al., 2002). We note, however, that the use of the Bennett and Robinson's (2000) measures as targeting deviance at that party is consistent with the literature that assesses sources of harm and targeted deviant reactions (e.g., Bechtoldt et al., 2007; Berry et al., 2007; Hershcovis et al., 2007; Jones, 2003; Jones, 2004; Mitchell and Ambrose, 2004; Mitchell and Ambrose, 2007).

\section{Results}

\section{Measurement model results}

We conducted confirmatory factor analyses (CFA) with LISREL 8 (Jöreskog \& Sörbom, 1996), using maximum likelihood estimation to evaluate the distinctness of the key study variables. The measurement model consisted of four factors: abusive supervision, authoritarian management style, organizational deviance, and interpersonal deviance items. The results indicate this model provided a good fit to the data $\left(\chi^{2}[813]=1769.36 ; p<.001\right)$; the fit indices were $\mathrm{RMSEA}=.059 ; \mathrm{CFI}=.96 ; \mathrm{NNFI}=.95$; AIC $=2043.08$. RMSEA scores below.08 (Hu \& Bentler, 1999) and CFI and NNFI scores at or above.90 (Bentler \& Bonnett, 1990) indicate an acceptable fit. The $\chi^{2}$ and the AIC values are used to compare the goodness of fit of the measurement model to alternative models. We compared the measurement model to three alternative models: a (1) one-factor deviance model (where organizational and interpersonal deviance were combined into one deviance factor and the other items were loaded on their respective measurement model factors $)\left(\chi^{2}[816]=1892.73, p<.001\right.$; RMSEA = .064; CFI = .95; NNFI = .95; AIC = 2243.66), (2) a onefactor predictor model (where abusive supervision and authoritarian management style items were combined into one predictor factor and the other items were loaded on their respective measurement model factors $)\left(x^{2}[816]=2361.90, p<.001\right.$; RM$\mathrm{SEA}=.076 ; \mathrm{CFI}=.93 ; \mathrm{NNFI}=.93 ; \mathrm{AIC}=2771.41)$, and $(3)$ a general one-factor model (where all items were loaded on one overall factor $)\left(x^{2}[819]=3243.45, p<.001 ;\right.$ RMSEA $=.11 ;$ CFI $=.89$; NNFI $=.89 ;$ AIC $=4798.97)$. The measurement model had a significant improvement in $\chi^{2}$ over the one-factor deviance model $\left(\Delta \chi^{2}[3]=123.37, p<.001\right)$, the one-factor predictor model $\left(\Delta \chi^{2}[3]=123.37, p<.001\right)$, and the general one-factor model $\left(\Delta \chi^{2}[6]=1474.09, p<.001\right)$, suggesting the measurement model produced a better fit than the alternative models (Schumacker \& Lomax, 1996). A comparison of AIC values shows that the measurement model had the smallest AIC value, suggesting superior fit compared to the alternative models (Akaike, 1987).

\section{Descriptive statistics and intercorrelations}

Descriptive statistics and correlations among the study variables are shown in Table 1.

\section{Hypotheses tests}

Prior to analysis, we centered all variables (except gender) both to minimize multicollinearity and to estimate meaningful values for the simple slope plot. Table 2 shows the results of the hypotheses tests.

Consistent with Hypothesis 1(a), authoritarian management style moderated the relationship between abusive supervision and organizational deviance; the interaction was significant $(b=-.11$, $\left.t=-2.78, p<.01, \Delta R^{2}=.02, \Delta F=7.75 p<.01\right)$. We examined the form of the interaction by testing the relationship between abusive supervision and organizational deviance at high (one SD above the mean) and low (one SD below the mean) values of authoritarian management style (Aiken \& West, 1991). This analysis revealed that the relationship between abusive supervision and organizational deviance was stronger positive for employees perceiving management style to be low authoritarian $(b=.45, t=5.35$, $p<.001)$ rather than high authoritarian $(b=.21, t=3.42, p<.01)$. The plotted interaction is shown in Figure 1. The pattern of this result supports Hypothesis 1(a).

Hypothesis 1(b) predicted authoritarian management style would moderate the relationship between abusive supervision and interpersonal deviance. However, the interaction was not sig- 
nificant $\left(b=-.04, t=-.71, n . s ., \Delta R^{2}=.00, \Delta F=.50\right.$, n.s.). Thus, the results do not provide support for Hypothesis $1(\mathrm{~b})$.

Hypothesis 2 predicts the authoritarian management style $\times$ abusive supervision interaction will more strongly influence the relationship between abusive supervision and organizational deviance than it will influence the relationship between abusive supervision and interpersonal deviance. The difference in the interactions $t$-values was $\Delta t=1.07$. The interaction between abusive supervision and authoritarian management style explained variance in organizational deviance, but not in interpersonal deviance. Consequently, Hypothesis 2 was supported.

\section{Supplemental analyses}

We conducted several supplemental analyses to further investigate the statistical conclusion validity of our findings. First, we conducted robust regression analyses that deal with various violations of OLS regression such as non-normality and outliers. Running these analyses on our data did not change the results of the hypothesized interaction on organizational $(b=-.12, t=-2.91$, $p<.01)$ and on interpersonal deviance $(b=-.09, t=-1.92, n . s$. $)$.
We also conducted an additional regression analysis without any control variables to rule out the control variables as an explanation

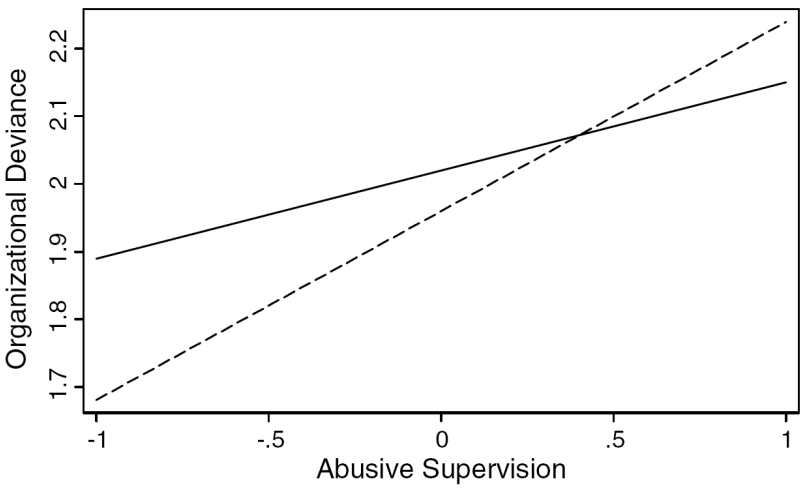

Authoritarian Management Style

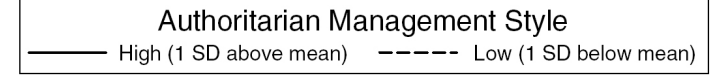

Figure 1. Study 1: Interaction between abusive supervision and authoritarian management style on organizational deviance.

Table 1. Study 1: Summary statistics and zero-order correlations

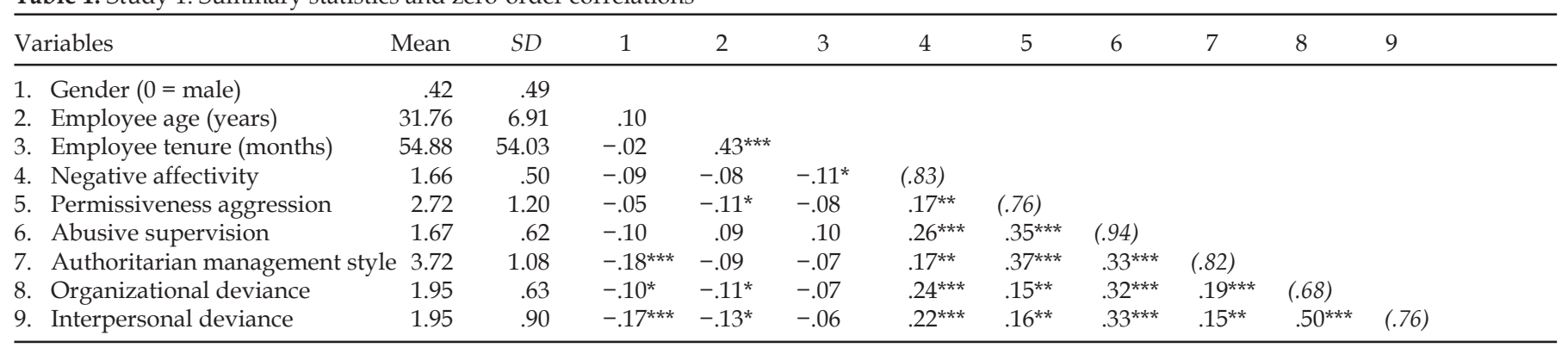

Note. $N=373$. Cronbach's alpha in parentheses along the diagonal.

${ }^{*} p<.05 . \quad{ }^{* *} p<.01 . \quad * * * p<.001$.

Table 2. Study 1: Regression for effect of abusive supervision $\times$ authoritarian management style interaction on organizational and interpersonal deviance

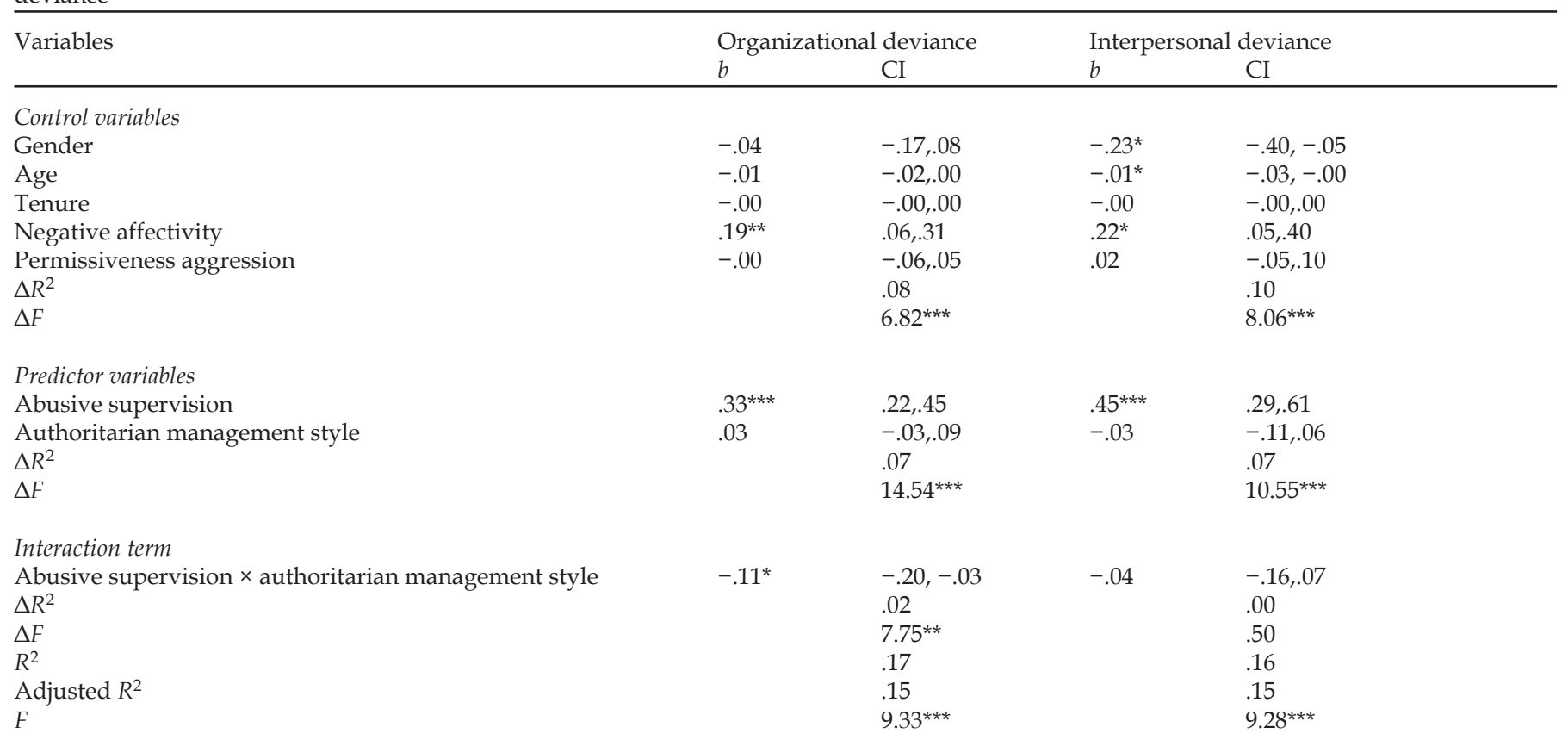

Note. $N=377$ (Organizational Deviance) and $N=390$ (Interpersonal Deviance). Effects are unstandardized regression coefficients. CI = $95 \%$ confidence interval.

${ }^{*} p<.05 . \quad * * p<.01 . \quad * * * p<.001$, two-tailed. 
of our findings. Becker (2005) suggests that to increase statistical conclusion validity of a study, it can be critical to show that the regression results are the same regardless of whether control variables are in the model or not. Again, we found a significant interaction on organizational deviance $(b=-.14, t=-3.43, p<.01$, $\left.\Delta R^{2}=.03, \Delta F=11.73, p<.01\right)$. The interaction on interpersonal deviance remained insignificant $\left(b=-.09, t=-1.51\right.$, n.s., $\Delta R^{2}=.00$ $\Delta F=2.28, n . s$.). That our finding remains the same with or without control variables indicates that control variable bias did not influence our results.

We conducted multilevel regression analysis to take into account that employees were nested within industries. Employees within similar industries may share common characteristics and this may result in statistical dependencies in the data. This can result in bias in the estimation of parameters and associated significance tests. Multilevel regression analysis takes these dependencies into account and possibly provides more accurate estimates (Snijders \& Bosker, 1999). The results of this analysis did not affect the significance or the pattern of the interaction on organizational deviance $(\gamma=-.12, z=-2.85, p<.01)$, nor did they affect the significance or the pattern of the interaction on interpersonal deviance $(\gamma=-.04$, $z=-.73, n . s$.).

\section{Study 1: Discussion}

Study 1 applied UMT to explain the relationship between abusive supervision and workplace deviance. According to our model, the extent to which the overall management style in the organization is authoritarian moderates the impact of abusive supervision on workplace deviance. Consistent with the idea that the influence of mistreatment on deviant employee behavior is stronger when employees experience situational uncertainty (Lind \& Van den Bos, 2002), we found that the positive relationship between abusive supervision and organizational deviance is stronger for employees perceiving the overall management style to be low authoritarian (or high situational uncertainty) than for employees perceiving the overall management style to be high authoritarian (or low situational uncertainty). We did not find a significant abusive supervision $\times$ authoritarian management style interaction on interpersonal deviance, however.

What our study implies is that employee's fundamental motivation to reduce uncertainty increases the impact of abusive supervision on deviance when employees work in unpredictable environments. The findings reported in this paper also extend current knowledge of uncertainty management in organizations by showing that uncertainty effects on the relationship between mistreatment and work behaviors are not limited to self-uncertainty (Thau et al., 2007) but also operate on a situational level. This is important because, arguably, organizations are better equipped to change the management style of authorities than the self-concepts of their employees.

Consistent with previous research, the results show abusive supervision directly and significantly relates to both organizational and interpersonal deviance (see Tepper, 2007 for a review). However, the findings of Study 1 are also supportive of the notion that employees seek to retaliate against the perceived source of the harm (e.g., Robinson \& Bennett, 1997). According to this view, the effect of supervisor abuse on deviance should be stronger against the source of mistreatment. Based on previous theories and associated findings (Skarlicki \& Folger, 1997), we argued that deviance against the organization can be conceptualized as deviance against authorities, as the authority is an agent of the organization's interests (Weber, 1947). We found support for this idea. The interactive effect between abusive supervision and authoritarian management style was significant for organizational deviance only. Thus, the results support Mitchell and Ambrose (2007) arguments that employees act out against coworkers and the organization when they experience supervisor abuse (i.e., direct effects). However, our results suggest that uncertainty only strengthens the relationship between abuse and organizational deviance, which suggests employees do not rectify the created imbalance via their fellow coworkers when they experience uncertainty and supervisor abuse; instead, they retaliate against the organization.

\section{Limitations}

The findings, however, should be considered in light of limitations. First, in Study 1 authoritarian management style was measured as an indirect assessment of uncertainty about management's actions and decisions. Authoritarian management style is only a proxy measure of uncertainty. While we argue authoritarianism suggests low uncertainty the measure itself did not evaluate perceptions of certainty. The moderating effects observed may reflect a more rigid style of employee monitoring, which would also influence employees' deviant behaviors. ${ }^{3}$

A second limitation of Study 1 was that we did not fully test the social exchange argument of retaliation. We suggested that employees would more likely retaliate against the source of the mistreatment, but we operationalized retaliatory behavior via their self-reported engagement in organizational deviance. We based this design on theoretical arguments for why deviant acts against the organization can be conceptualized as retaliatory behaviors against the supervisor (e.g., Skarlicki \& Folger, 1997). However, we did not assess whether deviance was targeted against the source of the abuse specifically. Recent research suggests the relevance of distinguishing interpersonal deviance based on specific targets of the behavior (i.e., supervisors, coworkers) (Hershcovis et al., 2007; Mitchell and Ambrose, 2007). Mitchell and Ambrose (2007) argue that retaliation against an abusive supervisor should be target-specific: employees victimized by an abusive supervisor should react against that supervisor, and the results from their study support this notion. Further, our measure of abusive supervision asks respondents to rate the frequency of abusive behavior perceived by "a supervisor or manager," which suggests respondents may have rated abusive behaviors in general throughout the organization, rather than acts targeted against the employee directly.

In light of these limitations, we believe the results of Study 1 provide suggestive evidence that individuals who are abused by their supervisor are more likely to engage in workplace deviance than those who are not abused, and that this relationship is attenuated when employees perceive the general management style in the organization as being authoritarian. We believe the results provide preliminary support for UMT and suggest that employees who are abused by their supervisor are more likely to engage in deviance when they face uncertainty about management's actions and decisions. The measures used in Study 1 do not provide a full test of our predictions, however. With this in mind, we conducted a second study to address the limitations.

\section{Study 2: Abusive supervision, supervisor-directed and orga- nizational deviance, and the moderating effects of uncertainty perceptions of management's actions and decisions}

Uncertain situations are often described as unpredictable (e.g., Knight, 1921; March, 1978; Marris, 1993; Pitz and Sachs, 1984), unexpected (e.g., Afifi and Burgoon, 2000; Inglis, 2000; Taleb, 2007), and surprising (e.g., Mazursky and Ofir, 1990; Wilson et al., 2005). Many writers believe that judging a situation as uncertain is one of the basic processes in social perception because perceiving

\footnotetext{
${ }^{3}$ We thank an anonymous reviewer for these observations.
} 
uncertainty was very likely relevant to survival when humans lived in hunter-gatherer communities (Stevens \& Fiske, 1995). Perhaps this is why people perceive and make judgments about uncertainty across various social spheres, including organizations (e.g., Downey and Slocum, 1975; O'Reilly et al., 1991). Here, we assume that employees perceive management's actions and decisions and directly evaluate them in terms of uncertainty as well. We measure such perceptions in Study 2 by asking employees directly about their perceptions of their organization's management's actions and decisions. Specifically, we ask employees whether management's actions and decisions are unpredictable or predictable, not surprising or surprising, and unexpected or expected.

We also further expand on the issue of retaliation and measure supervisor-directed deviance in Study 2. We draw from principles of retaliation elaborated by Mitchell and Ambrose (2007). Based on aggression theory (Anderson and Bushman, 2002; Berkowitz, 1993; Dollard et al., 1939), these authors argued that retaliation is most likely when employees believe they have been directly and aggressively provoked. Mitchell and Ambrose reduced Tepper's (2000) measure, and used the factor that represented employees' perceptions of active and aggressive abusive supervision. In an effort to appropriately capture retaliatory behavior, we adopt their arguments in Study 2 and measure active acts of abusive supervision that individuals believe are directly targeted against them, and we measure deviant acts that are directly targeted against the supervisor and those targeted at the organization (i.e., supervisordirected deviance, and organizational deviance). We test the following hypotheses:

\section{Hypothesis 3 - Employees' perceived uncertainty of manage- ment style will moderate the positive relationship between abu- sive supervision and employee engagement in (a) supervisor-di- rected and (b) organizational deviance such that the relationship will be stronger positive for employees perceiving high rather than low uncertainty of management style.}

Hypothesis 4 - The interactive effect between abusive supervision and employees' perceived uncertainty of management style, will be stronger for supervisor-directed than for organizational deviance.

\section{Study 2 method}

\section{Participants and procedure}

One thousand five hundred and ninety-one participants were recruited with the assistance of Zoomerang.com, an online data collection service that allows researchers to advertise their studies to adult online consumers. Zoomerang.com advertised our study to working adults who were employed either part-time or full-time in the United States. The age and annual household income of this online panel is largely comparable to those of the US Census (ZoomerangTM, 2005). Females are slightly overrepresented, however. In exchange for their participation in our study, participants received Zoomerang points for future purchases. Previously this panel has been used by e.g., researchers in the medical sciences (Becker, Schwartz, Saris-Baglama, Kosinski, \& Bjorner, 2007) and organizational behavior (Rogers \& Bazerman, 2007).

We restricted our data sample to those who provided complete and usable data for our variables of interest in this study (final sample size for analyses $=1477$ participants). Of the final sample, $50 \%$ were female, their average age was $39.92(S D=14.44)$ years, and their average tenure was $7.07(S D=8.18)$ years.
Measures

Abusive supervision: We used Mitchell and Ambrose's (2007) shortened five-item version of Tepper's (2000) measure. Respondents used a five-point scale $(1=$ never, $5=$ very often $)$ to indicate the frequency with which their supervisors engaged in active and abusive behaviors against them. Sample items are "My boss ridicules me," "My boss tells me my thoughts and feelings are stupid," and "My boss puts me down in front of others." Item scores were averaged $(a=.95)$.

Perceived uncertainty of management style: We created this measure based on a review of the literature that described uncertainty as containing the following judgments: surprise, unexpectedness, and unpredictability. Respondents indicated their answers to the following statements. "I find management's actions and decisions... unpredictable $(=1)$ vs. predictable $(=7)$ (reverse coded); not surprising $(=1)$ vs. surprising $(=7)$; unexpected (=1) vs. expected $(=7)$ (reverse coded). We averaged these items into a scale $(a=.74)$.

Workplace deviance: We assessed supervisor-directed deviance with Mitchell and Ambrose's (2007) 10-item measure. Sample item are: "Acted rudely toward my supervisor," "Made an obscene comment or gesture toward my supervisor," and "Swore at my supervisor." Respondents indicated the extent to which they intentionally engaged in the respective behaviors on a seven-point scale $(1=$ never, $7=$ daily $)$. Items were averaged $(a=.93)$. As in Study 1 , we used Bennett and Robinson's (2000) organizational deviance measure. Items were averaged $(a=.92)$.

Control variables: We controlled for the same set of variables as in Study 1. We controlled for age (in years), employee tenure (in years) and employee gender $(0=$ male, $1=$ female $)$. We excluded five cases from the analyses sample that provided unrealistically high values in terms of age, and/ or tenure. ${ }^{4}$ We also controlled for employees' trait negative affectivity (Watson et al., 1988) $(a=.92)$. Finally, we controlled for permissiveness towards aggression within the organization with the same scale as in Study $1(a=.76)$ to measure punishment expectations for retaliation.

\section{Results}

Measurement model results

We conducted confirmatory factor analyses (CFA) with LISREL 8 (Jöreskog \& Sörbom, 1996), using maximum likelihood estimation to evaluate the distinctness of the key study variables. The measurement model consisted of four factors: abusive supervision, perceived uncertainty of management style, organizational deviance, and supervisor-directed deviance items. The results indicate this model provided a good fit to the data $\left(\chi^{2}[371]=5646.02\right.$; $p<.001$ ); the fit indices were RMSEA $=.12$; $\mathrm{CFI}=.96$; NNFI $=.96$, $\mathrm{AIC}=9341.42$. The $\chi^{2}$ and the AIC values are used to compare the goodness of fit of the hypothesized model to alternative models. We compared the measurement model to three alternative models: a (1) one-factor deviance model (where organizational and supervisor-directed deviance were combined into one deviance factor and the other items were loaded on their respective measurement model factors $)\left(\chi^{2}[374]=6512.94, p<.001\right.$; RMSEA $=.13$; CFI = .96;

\footnotetext{
${ }^{4}$ Including or dropping these cases from the regression analysis did not influence the pattern or significance of the hypothesized effects.
} 
Table 3. Study 2: Summary statistics and zero-order correlations

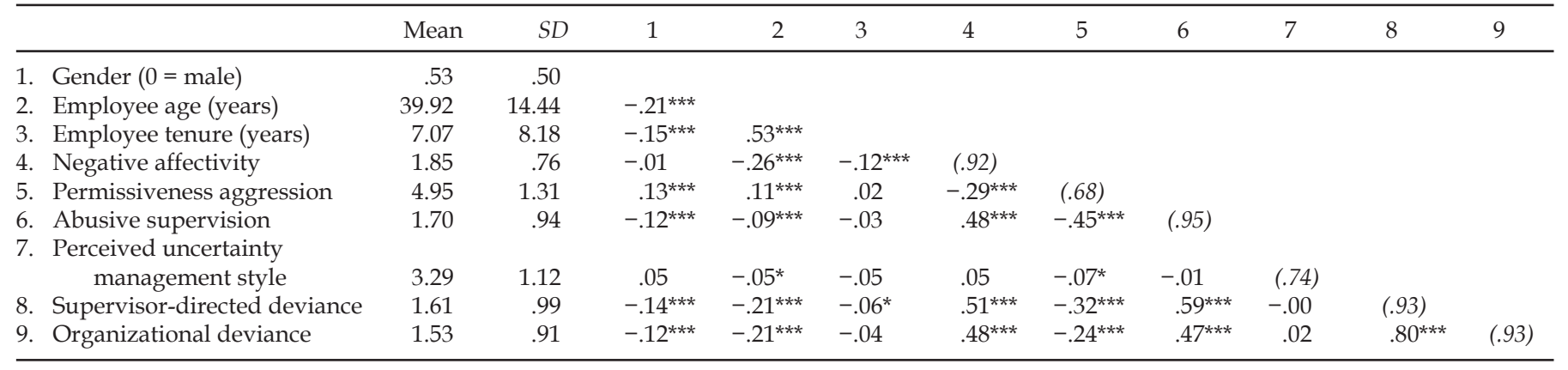

Note. $N=1477$. Cronbach's alpha in parentheses along the diagonal.

${ }^{*} p<.05$.

$* * * p<.001$.

NNFI $=.95 ; \quad$ AIC $=10518.44), \quad(2)$ a one-factor predictor model (where abusive supervision and perceived uncertainty were combined into one predictor factor and the other items were loaded on their respective measurement model factors $\left(\chi^{2}[374]=13647.52\right.$, $p<.001 ; \mathrm{RMSEA}=.18 ; \mathrm{CFI}=.91 ; \mathrm{NNFI}=.90 ; \mathrm{AIC}=20722.42)$, and (3) a general one-factor model (where all items were loaded on one overall factor $)\left(\chi^{2}[377]=13258.09, p<.001\right.$; RMSEA = .18; $\mathrm{CFI}=.91 ; \mathrm{NNFI}=.90 ; \mathrm{AIC}=19879.06$ ). The measurement model had a significant improvement in $\chi^{2}$ over the one-factor deviance model $\left(\Delta \chi^{2}[3]=866.92, p<.001\right)$, the one-factor predictor model $\left(\Delta \chi^{2}[3]=8001.5, p<.001\right)$, and the general one-factor model $\left(\Delta \chi^{2}[6]=7612.07, p<.001\right)$, suggesting the measurement model produced the best fit for the data compared to the alternative models (Schumacker \& Lomax, 1996). A comparison of AIC values shows that the measurement model had the smallest AIC value, suggesting superior fit compared to the alternative models (Akaike, 1987).

\section{Descriptive statistics and intercorrelations}

Descriptive statistics and correlations among the study variables are shown in Table 3.

\section{Hypothesis test}

Prior to analysis, we centered all variables (except gender) both to minimize multicollinearity and to estimate meaningful values for the simple slope plot. Table 4 shows the results of the hypotheses tests.

Consistent with Hypothesis 3(a), which predicts employees' perceived uncertainty of management style moderates the relationship between abusive supervision and deviance, the interaction for supervisor-directed deviance was significant $(b=.04$, $\left.t=2.41, p<.05, \Delta R^{2}=.00, \Delta F=5.79, p<.05\right) .{ }^{5}$ We examined the form of the interaction by testing the relationship between abusive supervision and supervisor-directed deviance at high (one $S D$ above the mean) and low (one $S D$ below the mean) values of perceived uncertainty of management style (Aiken \& West, 1991). This analysis revealed that the relationship between abusive supervision and supervisor-directed deviance was stronger positive for employees perceiving high $(b=.50, t=16.67, p<.001)$ rather

${ }^{5}$ It is notable that the explained variance by the interactions in Study 2 is below $1 \%$. However, the explained variance by interactions in field studies is generally small (Evans, 1985) and there is a welldocumented upward bias in explained variance in small samples (e.g., Snijders, 1996). This bias can explain why the explained variance in Study $1(N=377 / 390)$ is higher than in Study $2(N=1477)$. than low $(b=.42, t=12.97, p<.001)$ uncertainty of management style. The plotted interaction is shown in Figure 2. The pattern of this result supports Hypothesis 3(a).

We found a significant abusive supervision $\times$ employee assessments of management's actions and decisions interaction on organizational deviance $\left(b=.04, t=2.39, p<.05, \Delta R^{2}=.00, \Delta F=5.69\right.$, $p<.05)$, supporting Hypothesis $3(\mathrm{~b})$. We again conducted simple slope analysis to further examine the pattern of the interaction. This analysis revealed that the relationship between abusive supervision and organizational deviance was stronger positive for employees perceiving high $(b=.34, t=10.61, p<.001)$ rather than low uncertainty of management style $(b=.25, t=8.50, p<.001)$. The plotted interaction is shown in Figure 3. The pattern of this result further supports Hypothesis 3(b).

To test Hypothesis 4, we inspected the $t$-values of the parameter estimates for the interaction terms. Both interaction effects were significant and their difference was $\Delta t=.02$. This suggests little differences in the strength of the interaction effects. Thus, Hypothesis 4 was not supported.

\section{Supplemental analyses}

We again conducted several supplemental analyses to further investigate the statistical validity of our findings. First, we conducted robust regression analyses that deal with various violations of OLS regression such as non-normality and outliers. Running these analyses on our data did not change the results of the hypothesized interaction on supervisor-directed $(b=.03, t=4.40$, $p<.001)$ and organizational deviance $(b=.03, t=2.97, p<.01)$.

We also conducted an additional regression analysis without any control variables to rule out the control variables as an explanation of our findings (Becker, 2005). Again, we found a significant interaction on supervisor-directed deviance $(b=.06, t=3.32$, $\left.p<.01, \Delta R^{2}=.01, \Delta F=11.01, p<.01\right)$ and on organizational deviance $\left(b=.06, t=3.36, p<.01, \Delta R^{2}=.01, \Delta F=11.28, p<.001\right)$. That our finding remains the same with or without control variables indicates that control variable bias did not influence our results.

We conducted multilevel regression analysis to take into account that employees were nested within industries. Employees within similar industries may share common characteristics and this may result in statistical dependencies in the data. This can result in bias in the estimation of parameters and associated significance tests. Multilevel regression analysis takes these dependencies into account and possibly provides more accurate estimates (Snijders \& Bosker, 1999). The results of this analysis did not affect the significance or the pattern of the interaction on supervisor-directed deviance $(\gamma=.04, z=2.40, p<.01)$, nor did they affect the significance or the pattern of the interaction on organizational deviance $(r=.04, z=2.39, p<.05)$. 


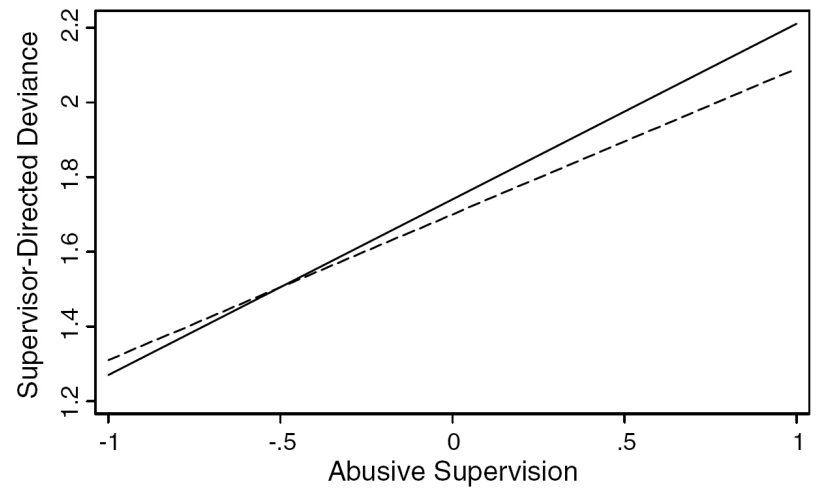

Perceived Uncertainty of Management Style High (1 SD above mean) -_--- Low (1 SD below mean)

Figure 3. Study 2: Interaction between abusive supervision and perceived uncertainty on organizational deviance.

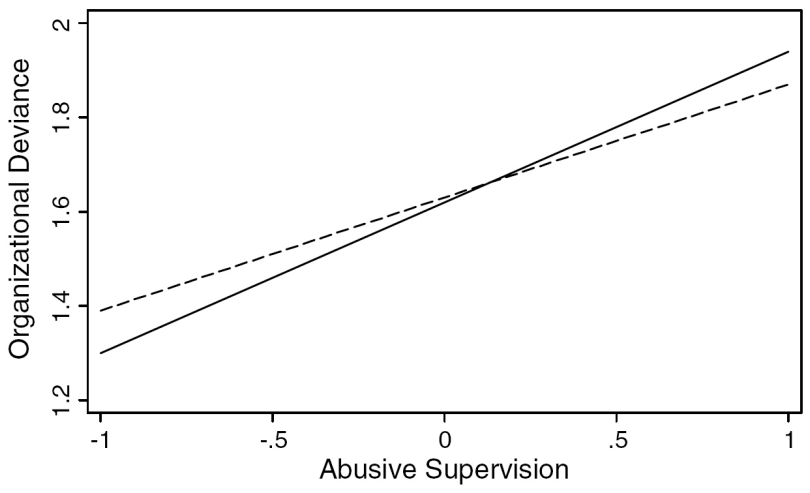

Perceived Uncertainty of Management Style High (1 SD above mean) ----- Low (1 SD below mean)

Figure 2. Study 2: Interaction between abusive supervision and perceived uncertainty of management style on supervisor-directed deviance.

\section{Study 2: Discussion}

The results of Study 2 suggest that employees' perceptions of uncertainty of their organization's management style moderate the relationship between abusive supervision and supervisorand organizational directed deviance. The pattern of the abusive supervision $\times$ perceived uncertainty of management style interaction on supervisor-directed and organizational deviance is comparable to the pattern of the abusive supervision $\times$ authoritarian management style interaction on organizational deviance in Study 1. Notably, in Study 2, we used different measures, collected data in a different context, and employed a different method of data collection.

We believe that Study 2 provides further evidence for our argument that situational uncertainty moderates the relationship between supervisor mistreatment and deviant behaviors. Study 1 assessed uncertainty perceptions only indirectly via authoritarian management style. Study 2 used a direct measure of employees' perceptions of uncertainty regarding management's actions and decisions, and captured the construct consistently with the literature on uncertainty by assessing perceptions of expectedness, surprise, and predictability (e.g., Afifi and Burgoon, 2000; Knight, 1921; March, 1978; Marris, 1993; Mazursky and Ofir, 1990; Pitz and Sachs, 1984; Taleb, 2007; Wilson et al., 2005). Assuming that people frequently make assessments of uncertainty in many social situations, including organizations (Downey \& Slocum, 1975), this
Table 4. Study 2: Regression for effect of abusive supervision $\times$ perceived uncertainty of management style interaction on supervisor-directed deviance and organizational deviance

\begin{tabular}{|c|c|c|c|c|}
\hline \multirow[t]{2}{*}{ Variables } & \multicolumn{2}{|c|}{$\begin{array}{c}\text { Supervisor-directed } \\
\text { deviance }\end{array}$} & \multicolumn{2}{|c|}{$\begin{array}{l}\text { Organizational } \\
\text { deviance }\end{array}$} \\
\hline & $b$ & $\mathrm{CI}$ & $b$ & $\mathrm{CI}$ \\
\hline \multicolumn{5}{|l|}{ Control variables } \\
\hline Gender & $-.21^{* * *}$ & $*-.29,-.13$ & $-.19^{* * *}$ & $-.27,-.11$ \\
\hline Age & $-.01^{* * *}$ & ${ }^{*}-.01,-.01$ & $-.01^{* * *}$ & $-.01, .01$ \\
\hline Tenure & .00 & $-.00, .01$ & $.01^{* *}$ & $.00, .01$ \\
\hline Negative affectivity & $.34^{* * *}$ & * $.28, .40$ & $.36^{* * *}$ & $.30, .42$ \\
\hline \multicolumn{5}{|l|}{ Permissiveness } \\
\hline$\Delta R^{2}$ aggression & -.02 & $\begin{array}{l}-.05, .02 \\
.31\end{array}$ & .01 & $\begin{array}{l}-.03, .04 \\
.27\end{array}$ \\
\hline$\Delta F$ & & $134.51^{* * *}$ & & $107.53^{* * *}$ \\
\hline \multicolumn{5}{|l|}{ Predictor variables } \\
\hline Abusive supervision & $.46^{* * *}$ & $.41, .51$ & $.30 * * *$ & $.25, .35$ \\
\hline $\begin{array}{l}\text { Perceived uncertainty } \\
\text { management style } \\
\Delta R^{2} \\
\Delta F\end{array}$ & $\begin{array}{l}\text { of } \\
-.02\end{array}$ & $\begin{array}{c}-.06, .01 \\
.12 \\
159.65^{* * *}\end{array}$ & -.00 & $\begin{array}{l}-.04, .03 \\
.06 \\
66.17^{* * *}\end{array}$ \\
\hline \multicolumn{5}{|l|}{ Interaction term } \\
\hline $\begin{array}{l}\text { Abusive supervision } \\
\times \text { perceived uncerta } \\
\text { management style }\end{array}$ & $\begin{array}{l}\text { inty of } \\
.04^{*}\end{array}$ & $.01, .07$ & $.04^{*}$ & $.01, .07$ \\
\hline$\Delta R^{2}$ & & .00 & & .00 \\
\hline$\Delta F$ & & $5.79^{*}$ & & $5.69^{*}$ \\
\hline$R^{2}$ & & .44 & & .33 \\
\hline Adjusted $R^{2}$ & & .44 & & .33 \\
\hline F & & $143.30^{* * *}$ & & $90.70^{* * *}$ \\
\hline
\end{tabular}

Note. $N=1477$. Effects are unstandardized regression coefficients. $\mathrm{CI}=95 \%$ confidence interval.

${ }^{*} p<.05 . \quad{ }^{* *} p<.01 . \quad{ }^{* * *} p<.001$, two-tailed.

measure may be more appropriate to operationalize perceptions of uncertainty related to management style. Nevertheless, future research is needed to further establish factors that can capture uncertainty perceptions in organizations.

Finally, the results of Study 2 provide more insight into retaliatory principles of social exchange. According to these models (e.g., Mitchell \& Ambrose, 2007), employees' deviant behaviors vis-àvis mistreatment should be strongest when the target of deviance was the source of the mistreatment. We found mixed support for this idea. When comparing the strength of the main effect of abusive supervision across the two regression equations, we found that this main effect was stronger on supervisor-directed deviance. However, we did not find support for this idea when uncertainty perceptions were included; the $t$-value for the interaction term between abusive supervision and perceived uncertainty of management style on supervisor-directed deviance was not substantially higher than the one for organizational deviance. This suggests that when confronted with uncertainty, there are no differences in the effect strength between supervisor abuse and organizational and supervisor-directed deviance.

\section{General discussion}

Two studies examined whether situational uncertainty represented in perceptions of management style moderates the relationship between abusive supervision and various forms of workplace deviance. In Study 1, the relationship between abusive supervision and organizational deviance was stronger positive for employees who perceived their organization's management style as high rather than low authoritarian. High (low) levels of author- 
itarian management style were argued to represent low (high) levels of uncertainty. These results are consistent with the UMTpredicted moderating effect of uncertainty on the abusive supervision-workplace deviance relationship. The results support retaliatory principles of social exchange as the interaction between abusive supervision and authoritarian management style was stronger for organizational than for interpersonal deviance.

Whereas Study 1's findings were consistent with UMT predictions, Study 2 provides direct support for UMT because we found that the relationship between abusive supervision and supervisor-directed and organizational deviance was stronger for employees who perceived high rather than low levels of uncertainty with respect to management style. The target-specific retaliation arguments were not supported in Study 2 based on our theoretical framework; the strength of the interaction effect between abusive supervision and perceived uncertainty of management style was the same for organizational and for supervisor-directed deviance. We explain these findings further below and discuss both the role of uncertainty and the role of the target in social exchange models of deviance.

\section{Implications for the role of uncertainty in social exchange models of deviance}

Social exchange theory provides a classical explanation for the relationship between supervisory mistreatment and workplace deviance. When employees are abused by authorities, they are more likely to exhibit behaviors that harm the organization and its members (see Tepper, 2007, for a review). Social exchange based models highlight that mistreated employees engage in harmful behaviors as a result. There are numerous variants of this explanation in organizational behavior, but one common theme is that perceptions of mistreatment matter for all in all contexts (Greenberg, 2001). A shortcoming of social exchange based models, then, is that they do not make predictions about when employees are more or less motivated to reciprocate the mistreatment they experience (e.g., Mitchell and Ambrose, 2007; Thau et al., 2007).

UMT emphasizes that people are very concerned about uncertainty (Lind \& Van den Bos, 2002). Accordingly, perceptions of situational uncertainty strengthen reactions towards mistreatment. We argued that employees who perceive uncertainty in their environment gauge the treatment they receive from supervisors to help them manage that uncertainty. This focus of attention makes interpersonal mistreatment more salient, and the associated retaliatory (deviant) behaviors more likely. The results of our studies provide both indirect (Study 1) and direct (Study 2) support for UMT's predictions. Together, they suggest that uncertainty plays a pivotal role in the strength of the abusive supervision-workplace deviance relationship.

The source of uncertainty in our studies was characterized by the organization's management style (or patterns of management's actions and decisions). Our conceptual treatment of uncertainty is consistent with a number of social cognition models that describe how people process information (in our study: uncertainty) from a social category (in our study: organizational authorities). Consequently, the treatment they receive from exemplars (supervisors) of that category becomes more salient to them. People react according to what information they process from the exemplar (in our study: quality of interpersonal supervisory treatment) (see e.g., Fiske, 1993; Fiske and Neuberg, 1990, for reviews on motivated information processing that flows from categories to exemplars).

It is interesting to note that UMT does not make differential predictions about different types of uncertainty and their effects on reactions to fairness-related information. Rather, the theory is so fundamental that even if there is no logical connection between the cause of the uncertainty and the fairness information, the uncer- tainty magnifies the reaction to the unfairness (Lind \& Van den Bos, 2002). For example, Van den Bos and Miedema (2000) report that asking participants to think about their own deaths strengthened their reactions to unfairness. In an organizational context, Tangirala and Alge (2006) found that unfair treatment by authorities had a stronger effect on fairness perceptions of an authority in computer-mediated (high uncertainty) rather than in face-to-face (low uncertainty) work groups. Nonetheless, although Lind and Van den Bos (2002) have argued that any type of uncertainty will increase the salience of fairness-related information and its consequences, we believe future research should investigate uncertainty that is cognitively not coupled with the fairness information (like in the Tangirala \& Alge study) against uncertainty that is cognitively coupled with the fairness information and test which influences the salience of unfairness to a stronger extent (like in our study).

Whereas our paper provides two different ways to measure uncertainty with respect to management style, the measure presented in Study 2 is more directly tied to characteristics of uncertainty as implied in the uncertainty literature (e.g., Knight, 1921; Marris, 1993; Mazursky and Ofir, 1990; McDaniel and Driebe, 2005; Taleb, 2007). Most studies of UMT in social psychology use priming/recall procedures to manipulate situational uncertainty (e.g., Van den Bos, 2001; Van den Bos and Lind, 2002). This manipulation involves asking students to recall and to write about a situation in which they felt uncertain. There are, to our knowledge, no content analyses of these data available and so we do not know which elements of uncertainty are responsible for the results found in that stream of research. Consequently, there is little theoretical guidance as to what characteristics of uncertainty should be included in a measure of situational uncertainty. Our study is a first attempt to fill this gap. Based on our review of the uncertainty literature, there are three defining elements of uncertainty: surprise, unexpectedness, and unpredictability. Future research is needed to further develop a comprehensive measure of perceived uncertainty of management style, which is beyond the scope of our paper.

Further, research has yet to explore other effects of uncertainty in terms of social exchange relations. While our study assesses the influence of uncertainty on abusive employee-supervisor social exchange relations, the literature suggests employees differentiate social exchange relations with different members in their organizations (e.g., those with coworkers, teams, and the organization more generally; see Cropanzano \& Mitchell, 2005 for a review). Future research is needed to explore the influence of uncertainty in different exchange relations, as well as in terms of other consequences of poor-quality exchanges (e.g., citizenship behavior, performance, absenteeism, commitment).

Implications for the role of the deviance target in social exchange models of deviance

Unlike UMT and its applications to organizational behavior (Colquitt et al., 2006; Thau et al., 2007), social exchange-based models of workplace deviance suggest that there are target-specific variations in the abusive supervision-workplace deviance relationship. Specifically, this stream of research implies that the relationship between abusive supervision and workplace deviance should be strongest for deviant behaviors that are closely targeted towards authorities (Mitchell \& Ambrose, 2007) and the organization they represent (cf. Skarlicki \& Folger, 1997). In this study, we extended UMT principles to advance the idea that the interaction between abusive supervision and uncertainty perceptions should also be stronger for deviant behaviors that are tied to the source of the mistreatment.

We found mixed support for this notion. For Study 1, we expected and found the interaction between abusive supervision and authoritarian management style on organizational deviance to be 
stronger than on interpersonal deviance because supervisors are agents of the organization's interests. By harming the organization, employees can get back at their abusive supervisors (Skarlicki \& Folger, 1997). In contrast, interpersonal deviance involves deviance against all members of the organization and possibly against many that were never involved in the abuse. In general, individuals interpret interpersonal deviance to be harmful behavior directed against coworkers in organizations (Mitchell \& Ambrose, 2007). Ergo, the interaction should be less strong on interpersonal deviance, which is what we found. The findings of Study 1 suggest uncertainty does not strengthen deviant reactions in general, but does strengthen retaliatory reactions. Thus, uncertainty magnifies social exchange principles regarding mistreatment.

Whereas Study 2 fully supported UMT predictions, we did not find differences in the strength of the interaction on supervisordirected and organizational deviance. There are various plausible explanations for this finding. A first explanation is that the target perspective of social exchange is incomplete and needs to consider additional moderators that explain when employees chose to retaliate against supervisors by supervisor-directed rather than organizational deviance and vice versa. Such conditions may include perceptions of powerlessness (Bennett, 1998; Martinko et al., 2002) - employees who feel powerless may conceive organizational deviance as a feasible form of retaliation than engaging in harmful behaviors towards the source of the mistreatment. Any other variable that speaks to the perceived dependence/power of the mistreated employee could be tested by future research as an additional moderator and may consequently explain differences in deviance across targets. This approach would be consistent with power theories of social exchange (Emerson, 1976).

Another, related, explanation for the failure to find differences in the strength of the interaction effect may be that the correlation between supervisor-directed and organizational deviance was very high. Notably, this correlation was higher than the one between interpersonal and organizational deviance in Study 1 . The high correlation between organizational and supervisor-directed suggests that many employees who engage in organizational deviance engage in supervisor-directed deviance as well, which may make it difficult to find differential effects empirically (cf. Cohen, Cohen, West, \& Aiken, 2003).

\section{Limitations}

First, as our data are cross-sectional, we could not test definitively the hypotheses that the variables we studied, either singly or in combination, actually caused deviant behavior. Although our results are consistent with previous findings on abusive supervision and deviance and there are stronger theoretical reasons for proposing such relationships than for the opposite direction of causality, we are cautious about making causal inferences because of the nature of our study design. It is difficult, of course, to manipulate abusive supervision to test this effect directly, but future research should attempt to study this phenomenon at multiple points in time to better assess causality.

Secondly, all of our data were obtained through self-report which suggest potential measurement bias. We believe, however, that anonymous self-report is an acceptable way to measure perceptual constructs such as abusive supervision and uncertainty, as well as harmful, norm-violating behaviors such as organizational deviance. Past research has shown, in fact, that underreporting may not be as much of a problem as anticipated because employees appear to be surprisingly candid about their participation in deviant and even illegal behavior (Bennett \& Robinson, 2000). In addition, recent perspectives on common method variance suggest that this phenomenon is sometimes overstated and hence unlikely to inflate correlations to any significant degree (Spector, 2006). Nonetheless, future research should try to assess these variables using multiple sources.
Finally, our hypotheses suggested who would be the target of the deviant behavior, but our measures assessed who is harmed by the action, not necessarily who the intended target was. As Ambrose and her colleagues point out (Ambrose et al., 2002), it may be that the recipient of the harmful behavior may diverge from the target of the harm due to displaced aggression (e.g., an abused subordinate may passively retaliate by failing to complete his share of the workload, but his coworkers are the ones who bear the brunt of the deviance, not the supervisor or the organization). Future research should attempt to measure the intended target of workplace deviance rather than focusing only on who was harmed by the behavior.

\section{Conclusion}

Uncertainty plays a fundamental role in people's lives and can explain why and when employees engage in workplace deviance when they experience abuse by authorities. UMT provides a useful extension of social exchange-based explanations of workplace deviance and may help to understand the motivational foundations of harmful behaviors in organizations. Future research is needed to delineate the boundaries of this explanation.

\section{Acknowledgment}

We thank Gillian Ku and Madan Pillutla for helpful comments on previous versions of this manuscript.

\section{References}

Adorno et AL., 1950 - T.W. Adorno, E. Frenkel-Brunswik, D.J. Levinson and R.N. Sanford, The authoritarian personality, Harpers, Oxford (1950).

Afifi And Burgoon, 2000 - W.A. Afifi and J.K. Burgoon, The impact of violations on uncertainty and the consequences for attractiveness, Human Communication Research 26 (2000), pp. 203-234.

Aiken And West, 1991 - L.S. Aiken and S.G. West, Multiple regression: Testing and interpreting interactions, Sage, Newbury Park, CA (1991).

AKAIKe, 1987 - H. Akaike, Factor analysis and AIC, Psychometrika 52 (1987), pp. 317-332.

AltEMEYER, 1988 - B. Altemeyer, Enemies of freedom: Understanding right-wing authoritarianism, Jossey-Bass, San Francisco (1988).

Ambrose And Schminke, 2003 - M.L. Ambrose and M. Schminke, Organization structure as a moderator of the relationship between procedural justice, interactional justice, perceived organizational support, and supervisory trust, Journal of Applied Psychology 88 (2003), pp. 295-305.

Ambrose et Al., 2002 - M.L. Ambrose, M.A. Seabright and M. Schminke, Sabotage in the workplace: The role of organizational justice, Organizational Behavior and Human Decision Processes 89 (2002), pp. 947-965.

Anderson and Bushman, 2002 - C.A. Anderson and B.J. Bushman, Human aggression, Annual Review of Psychology 53 (2002), pp. 27-51.

Aquino and Douglas, 2003 - K. Aquino and S. Douglas, Identity threat and antisocial behavior in organizations: The moderating effects of individual differences, aggressive modeling, and hierarchical status, Organizational Behavior and Human Decision Processes 90 (2003), pp. 195-208.

Aquino ET AL., 1999 - K. Aquino, M.U. Lewis and M. Bradfield, Justice constructs, negative affectivity, and employee deviance: A proposed model and empirical test, Journal of Organizational Behavior 20 (1999), pp. 1073-1091.

Aquino ET AL., 2001 - K. Aquino, T.M. Tripp and R.J. Bies, How employees respond to personal offense: The effects of blame attribution, victim status, and offender status on revenge and reconciliation in the workplace, Journal of Applied Psychology 86 (2001), pp. 52-59.

AshFord and Cummings, 1983 - S.J. Ashford and L.L. Cummings, Feedback as an individual resource: Personal strategies for creating information, Organizational Behavior and Human Performance: 32 (1983), pp. 370-389.

Ashford And Cummings, 1985 - S.J. Ashford and L.L. Cummings, Proactive feedback seeking: The instrumental use of the information environment, Journal of Occupational Psychology 58 (1985), pp. 67-79.

AsHForTh, 1997 - B. Ashforth, Petty tyranny in organizations: A preliminary examination of antecedents and consequences, Canadian Journal of Administrative Sciences 14 (1997), pp. 126-140.

Baron and Neuman, 1996 - R.A. Baron and J.H. Neuman, Workplace violence and workplace aggression: Evidence of their relative frequency and potential causes, Aggressive Behavior 22 (1996), pp. 161-173.

BARON ET AL., 1999 - R.A. Baron, J.H. Neuman and D. Geddes, Social and per- 
sonal determinants of workplace aggression: Evidence for the impact of perceived injustice and the type A behavior pattern, Aggressive Behavior 25 (1999), pp. 281-296.

Bechtoldt ET AL., 2007 - M.N. Bechtoldt, C. Welk, J. Hartig and D. Zapf, Main and moderating effects of self-control, organizational justice, and emotional labor on counterproductive behavior at work, European Journal of work and Organizational Psychology 16 (2007), pp. 479-500.

BeCKer et AL., 2007 - J. Becker, C. Schwartz, R.N. Saris-Baglama, M. Kosinski and J.B. Bjorner, Using item response theory (IRT) for developing and evaluating the pain impact questionnaire (PIQ-6TM), Pain Medicine 8 (2007), pp. 129-144.

BECKER, 2005 - T.E. Becker, Potential problems in the statistical control of variables in organizational research: A qualitative analysis with recommendations, Organizational Research Methods 8 (2005), pp. 274-289.

BennetT, 1998 - R.J. Bennett, Perceived powerlessness. In: R. Griffin, A. O'LearyKelly and J. Collins, Editors, Dysfunctional behavior in organizations: Violent and deviant behavior, JAI, Stamford, CT (1998), pp. 221-239.

BennetT And Robinson, 2000 - R.J. Bennett and S.L. Robinson, The development of a measure of workplace deviance, Journal of Applied Psychology 85 (2000), pp. 349-360.

Bennett and Robinson, 2003 - R.J. Bennett and S.L. Robinson, The past, present, and future of workplace deviance research. In: J. Greenberg, Editor, Organizational behavior: The state of science (2nd ed.), LEA, Mahwah, NJ (2003), pp. 247-281.

Bentler And BonnetT, 1990 - P.M. Bentler and D.G. Bonnett, Significance tests and goodness of fit in the analysis of covariance structures, Psychological Bulletin 88 (1990), pp. 588-606.

Berkowitz, 1993 - L. Berkowitz, Aggression: Its causes, consequences, and control, McGraw-Hill, NY (1993).

BERRY ET AL., 2007 - C.M. Berry, D.S. Ones and P.R. Sackett, Interpersonal deviance, organizational deviance, and their common correlates: A review and meta-analysis, Journal of Applied Psychology 92 (2007), pp. 410-424.

BIES, 2001 - R.J. Bies, Interactional (in)justice: The sacred and the profane. In: J. Greenberg and R. Cropanzano, Editors, Advances in organizational justice, Stanford University Press, Stanford, CA (2001), pp. 89-118.

BIES AND MoAG, 1986 - R.J. Bies and J.S. Moag, Interactional justice: Communication criteria of fairness. In: R. Lewicki, B. Sheppard and M. Bazerman, Editors, Research on negotiations in organizations, JAI Press, Greenwich, CT (1986), pp. 43-53.

BIES AND TRIPP, 1997 - R.J. Bies and T.M. Tripp, What's good about revenge? The avenger's perspective. In: R.J. Lewicki, R.J. Bies and B.H. Sheppard, Editors, Research on negotiation in organizations 6, JAI Press, Greenwich, CT (1997), pp. 145-160.

BiES AND TRIPP, 1998A - R.J. Bies and T.M. Tripp, Revenge in organizations: The good, the bad, and the ugly. In: R.W. Griffin, A. O'Leary Kelly and J.M. Collins, Editors, Dysfunctional behavior in organizations: Non-violent dysfunctional behavior, JAI, Stamford, CT (1998), pp. 49-67.

BIES AND TRIPP, 1998B - R.J. Bies and T.M. Tripp, Two faces of the powerless: Coping with tyranny in organizations. In: R.M. Kramer and M.A. Neal, Editors, Power and influence in organizations, Sage, Thousand Oaks, CA (1998), pp. 203-220.

BINGHAM AND SCHERER, 1993 - S.G. Bingham and L.L. Scherer, Factors associated with responses to sexual harassment and satisfaction with outcome, Sex Roles 29 (1993), pp. 239-269.

BLau, 1964 - P.M. Blau, Exchange and power in social life, Wiley, NY (1964).

Burns AND STALKer, 1961 - T. Burns and G.M. Stalker, The management of innovation, Tavistock, London (1961).

Cohen et AL., 2003 - J. Cohen, P. Cohen, S.G. West and L.S. Aiken, Applied multiple regression/correlation analysis for the behavioral sciences, Lawrence Erlbaum, Mahwah, NJ (2003).

Colquitt and Greenberg, 2003 - J.A. Colquitt and J. Greenberg, Organizational justice: A fair assessment of the state of the literature. In: J. Greenberg, Editor, Organizational behavior: The state of the science, Lawrence Erlbaum, Mahwah, NJ (2003), pp. 165-210.

Colquitt ET AL., 2006 - J.A. Colquitt, B.A. Scott, T.A. Judge and J.C. Shaw, Justice and personality: Using integrative theories to derive moderators of justice effects, Organizational Behavior and Human Decision Processes 100 (2006), pp. $110-127$.

Covin And Slevin, 1988 - J.G. Covin and D.P. Slevin, The influence of organization structure on the utility of an entrepreneurial top management style, Journal of Management Studies 25 (1988), pp. 217-234.

Cropanzano et AL., 2001 - R. Cropanzano, Z.S. Byrne, D.R. Bobocel and D.E. Rupp, Moral virtues, fairness heuristics, social entities, and other denizens of organizational justice, Journal of Vocational Behavior 58 (2001), pp. 164-209.

Cropanzano and Mitchell, 2005 - R. Cropanzano and M.S. Mitchell, Social exchange theory: An interdisciplinary review, Journal of Management 31 (2005), pp. 874-900.

Detert et AL., 2007 - J.R. Detert, L.K. Treviño, E.R. Burris and M. Andiappan, Managerial modes of influence and counter productivity in organizations: A longitudinal business-unit-level investigation, Journal of Applied Psychology 92 (2007), pp. 993-1005.
Dixon ET AL., 2007 - S.E.A. Dixon, K.E. Meyer and M. Day, Exploitation and exploration learning and the development of organizational capabilities: A cross-case analysis of the Russian oil industry, Human Relations 60 (2007), pp. 1493-1523.

Dollard ET AL., 1939 - J. Dollard, L.W. Doob, N.E. Miller, O.H. Mowrer and R.R. Sears, Frustration and aggression, Yale University Press, New Haven, CT (1939).

Downey and Slocum, 1975 - H.K. Downey and J.W. Slocum, Uncertainty: Measures, research, and sources of variation, Academy of Management Journal 18 (1975), pp. 562-578.

DuCKITT, 1989 - J. Duckitt, Authoritarianism and group identification: A new view of an old construct, Political Psychology 10 (1989), pp. 63-84.

DuckiтT, 1992 - J. Duckitt, The social psychology of prejudice, Praeger publisher, NY (1992).

EISENBERGER ET AL., 2002 - R. Eisenberger, F. Stinglhamber, C. Vandenberghe, I. Sucharski and L. Rhoades, Perceived supervisor support: Contributions to perceived organizational support and employee retention, Journal of Applied Psychology 87 (2002), pp. 565-573.

EMERSon, 1976 - R.M. Emerson, Social exchange theory, Annual Review of Sociology 2 (1976), pp. 353-362.

Evans, 1985 - M.G. Evans, A Monte Carlo study of the effects of correlated method variance in moderated multiple regression analysis, Organizational Behavior and Human Decision Processes 36 (1985), pp. 305-323.

FAy AND Frese, 2000 - D. Fay and M. Frese, Conservatives' approach to work: Less prepared for future work demands?, Journal of Applied Social Psychology 30 (2000), pp. 171-195.

FELDMAN, 2003 - S. Feldman, Enforcing social conformity: A theory of authoritarianism, Political Psychology 24 (2003), pp. 41-74.

FISKE, 1993 - S.T. Fiske, Social cognition and social perception, Annual Review of Psychology 44 (1993), pp. 155-194.

FiSKE AND NEUbERG, 1990 - S.T. Fiske and S.L. Neuberg, A continuum of impression formation, from category-based to individuating processes: Influences of information and motivation on attention and interpretation, Advances in Experimental Social Psychology 23 (1990), pp. 1-74.

Fromm, 1945 - E. Fromm, Die furcht vor der freiheit, Steinberg, Zurich (1945).

Gouldner, 1960 - A. Gouldner, The norm of reciprocity, American Sociological Review 25 (1960), pp. 161-178.

GREENBERG, 2001 - J. Greenberg, The seven loose can(n)ons of organizational justice. In: J. Greenberg and R. Cropanzano, Editors, Advances in organizational justice, Stanford University Press, Stanford, CA (2001), pp. 245-271.

HARRIS ET AL., 2007 - K.J. Harris, K.M. Kacmar and S. Zivnuska, An investigation of abusive supervision as a predictor of performance and the meaning of work as a moderator of the relationship, Leadership Quarterly 18 (2007), pp. 252-263.

Heaven, 1985 - P.C. Heaven, Construction and validation of a measure of authoritarian personality, Journal of Personality Assessment 49 (1985), pp. $545-551$.

Hershcovis et AL., 2007 - S.M. Hershcovis, N. Turner, J. Barling, K.A. Arnold, K.E. Dupre and M. Inness et al., Predicting workplace aggression: A metaanalysis, Journal of Applied Psychology 92 (2007), pp. 228-238.

Hodson AND Sorrentino, 1999 - G. Hodson and R.M. Sorrentino, Uncertainty orientation and the big five personality structure, Journal of Research in Personality 33 (1999), pp. 253-261.

Hogan, 1983 - R. Hogan, A socioanalytic theory of personality. In: M.M. Page, Editor, Nebraska symposium on motivation, University of Nebraska Press, Lincoln (1983), pp. 55-89 1982.

HogG, 2001 - M.A. Hogg, Self-categorization and subjective uncertainty resolution: Cognitive and motivational facets of social identity and group membership. In: J.P. Forgas, K.D. Williams and L. Wheeler, Editors, The social mind: Cognitive and motivational aspects of interpersonal behavior, Cambridge University Press, NY (2001), pp. 323-349.

Hogg And Muluin, 1999 - M.A. Hogg and B.A. Mullin, Joining groups to reduce uncertainty: Subjective uncertainty reduction and group identification. In: D. Abrams and M.A. Hogg, Editors, Social identity and social cognition, Blackwell Publishing, Malden, MA (1999), pp. 249-279.

Hu ANd Bentler, 1999 - L. Hu and P. Bentler, Cutoff criteria for fit indexes in covariance structure analysis: Conventional criteria versus new alternatives, Structural Equation Modeling 6 (1999), pp. 1-55.

INGLIS, 2000 - I.R. Inglis, Review: The central role of uncertainty reduction in determining behavior, Behavior 137 (2000), pp. 1567-1599.

INNES ET AL., 2005 - M. Innes, J. Barling and N. Turner, Understanding supervisor-targeted aggression: Within-person, between-jobs design, Journal of Applied Psychology 90 (2005), pp. 731-739.

JONES, 2003 - D.A. Jones, Predicting retaliation in the workplace: The theory of planned behavior and organizational justice, Academy of Management Proceedings (2003), pp. A1-A6 OB.

JoNES, 2004 - D.A. Jones, Counterproductive work behavior toward supervisors and organizations: Injustice, revenge, and context, Academy of Management Proceedings (2004), pp. L1-L6 OB.

JÖRESKOG AND SÖRBOM, 1996 - K.G. Jöreskog and D. Sörbom, LISREL 8: User's reference guide, Scientific Software International, Chicago (1996). 
Jost et AL., 2003 - J. Jost, J. Glaser, A. Kruglanski and F. Sulloway, Political conservatism as motivated social cognition, Psychological Bulletin 129 (2003), pp. 339-375.

KEASHLY, 1998 - L. Keashly, Emotional abuse in the workplace: Conceptual and empirical issues, Journal of Emotional Abuse 1 (1998), pp. 85-117.

Keashly et AL., 1994 - L. Keashly, V. Trott and L. MacLean, Abusive behavior in the workplace: A preliminary investigation, Violence and Victims 9 (1994), pp. 341-357.

KNIGHT, 1921 - F.H. Knight, Risk, uncertainty, and profit, Houghton Mifflin, Boston, MA (1921)

JANSSENS ET AL., 1995 - M. Janssens, J. Brett and F. Smith, Confirmatory crosscultural research: Testing the viability of a corporation-wide safety policy, Academy of Management Journal 38 (1995), pp. 365-382.

Jost ET AL., 2003 - J. Jost, J. Glaser, A. Kruglanski and F. Sulloway, Political conservatism as motivated social cognition, Psychological Bulletin 129 (3) (2003), pp. 339-375.

KeAshly ET AL., 1994 - L. Keashly, V. Trott and L.M. MacLean, Abusive behavior in the workplace: A preliminary investigation, Violence and victims 9 (1994), pp. 125-141.

LEVENTHAL, 1980 - G.S. Leventhal, What should be done with equity theory? In: K.J. Gergen, M.S. Greenberg and R.H. Willis, Editors, Social exchange: Advances in theory and research, Plenum, New York (1980), pp. 27-55.

LeVINSON, 1965 - H. Levinson, Reciprocation: The relationship between man and the organization, Administrative Science Quarterly 9 (1965), pp. 370-390.

LiND ET AL., 2000 - E.A. Lind, J. Greenberg, K.S. Scott and T.D. Welchans, The winding road from employee to complainant: Situational and psychological determinants of wrongful termination claims, Administrative Science Quarterly 45 (2000), pp. 557-590.

LIND AND TYLER, 1988 - E.A. Lind and T.R. Tyler, The social psychology of procedural justice, Plenum Press, New York (1988).

LiND AND VAN DEN Bos, 2002 - E.A. Lind and K. Van den Bos, When fairness works: Toward a general theory of uncertainty management. In: B.M. Staw and R.M. Kramer, Editors, Research in organizational behavior Vol. 24, JAI Press, Greenwich, CT (2002), pp. 181-223.

MARCH, 1978 - J.G. March, Bounded rationality, ambiguity, and the engineering of choice, Bell Journal of Economics 9 (1978), pp. 587-608.

Marris, 1993 - P. Marris, The social construction of uncertainty. In: C. Parkes, J. Stevenson-Hinde and P. Marris, Editors, Attachment across the life cycle, Routledge, London (1993).

MartinKo ET AL., 2002 - M.J. Martinko, M.J. Gundlach and S.C. Douglas, Toward an integrative theory of counterproductive workplace behavior: A causal reasoning perspective, International Journal of Selection and Assessment 10 (2002), pp. 36-41.

MASTERSON ET AL., 2000 - S.S. Masterson, K. Lewis, B.M. Goldman and M.S. Taylor, Integrating justice and social exchange: The differing effects of fair procedures and treatment on work relationships, Academy of Management Journal 43 (2000), pp. 738-748.

MAZURSKY AND Ofir, 1990 - D. Mazursky and C. Ofir, I could never have expected it to happen. The reversal of the hindsight bias, Organizational Behavior and Human Decision Processes 46 (1990), pp. 20-33.

McAllister And Anderson, 1991 - P. McAllister and A. Anderson, Conservativism and the comprehension of implausible texts, European Journal of Social Psychology 21 (1991), pp. 147-164.

McDaniel and DrIebe, 2005 - R.R. McDaniel and D.J. Driebe, Uncertainty and surprise in complex systems: Questions on working with the unexpected, Springer, Berlin (2005).

McGREGor, 1960 - D.M. McGregor, The human side of the enterprise, McGraw Hill, New York (1960).

Mitchell And Ambrose, 2004 - Mitchell, M. S., \& Ambrose, M. L. (2004). Is workplace deviance a victim's response to unfair exchange? Society for industrial and organizational psychology annual meeting, Chicago, IL. Unpublished manuscript.

Mitchell And Ambrose, 2007 - M.S. Mitchell and M.L. Ambrose, Abusive supervision and workplace deviance and the moderating effects of negative reciprocity beliefs, Journal of Applied Psychology 92 (2007), pp. 1159-1168.

Molm AND CoOK, 1995 - L.D. Molm and K.S. Cook, Social exchange and exchange networks. In: K.S. Cook, G.A. Fine and J.S. House, Editors, Sociological perspectives on social psychology, Allyn \& Bacon, Boston (1995), pp. 209-235.

O’Reilly et AL., 1991 - C.A. O’Reilly III, J.A. Chatman and D.F. Caldwell, People and organizational culture: A profile comparison approach to assessing person-organization fit, Academy of Management Journal 34 (1991), pp. 487-516.

Peterson et AL., 1993 - B. Peterson, R. Doty and D. Winter, Authoritarianism and attitudes toward contemporary social issues, Personality and Social Psychology Bulletin 19 (1993), pp. 678-690.

Pitz And SACHS, 1984 - G.F. Pitz and N.J. Sachs, Judgment and decision: Theory and application, Annual Review of Psychology 35 (1984), pp. 139-163.

Robinson And BenNetT, 1997 - S.L. Robinson and R.J. Bennett, Workplace deviance: Its definition, its manifestations, and its causes. In: R. Lewicki, B. Sheppard and M. Bazerman, Editors, Research on negotiations in organizations, JAI Press, Greenwich, CT (1997), pp. 3-27.

Rogers AND BAZERMAN, 2007 - T. Rogers and M.H. Bazerman, Future lock-in: Future implementation increases selection of 'should' choices, Organizational Behavior and Human Decision Processes 106 (2007), pp. 1-20.
SCHumacker AND Lomax, 1996 - R.E. Schumacker and R.G. Lomax, A beginner's guide to structural equation modeling, Lawrence Erlbaum Associates, Mahwah, NJ (1996).

SkARlicki AND Folger, 1997 - D.P. Skarlicki and R. Folger, Retaliation in the workplace: The role of distributive, procedural, and interactional justice, Journal of Applied Psychology 82 (1997), pp. 434-443.

SKARLICKI AND FOLGER, 2004 - D.P. Skarlicki and R. Folger, Broadening our understanding of organizational retaliatory behavior. In: R.W. Griffin and A.m. O'Leary-Kelly, Editors, The dark side of organizational behavior, Jossey-Bass, San Francisco, CA (2004), pp. 373-402.

SNIJDERS, 1996 - T.A.B. Snijders, What to do with the upward bias in R ${ }^{2}$ : A comment on Huberty, Journal of Educational and Behavioral Statistics 21 (1996), pp. 283-287.

SNIJDERS AND BOSKer, 1999 - T. Snijders and R. Bosker, Multilevel analysis: An introduction to basic and advanced multilevel modeling, Sage Publications, London (1999).

SPECTOR, 2006 - P.E. Spector, Method variance in organizational research: Truth or urban legend, Organizational Research Methods 9 (2006), pp. 221-232.

Stellmacher and Petzel, 2005 - J. Stellmacher and T. Petzel, Authoritarianism as a group phenomenon, Political Psychology 26 (2005), pp. 245-274.

Stevens And FISKe, 1995 - L.S. Stevens and S.T. Fiske, Motivation and cognition in social life: A social survival perspective, Social Cognition 13 (1995), pp. $189-214$.

TALEB, 2007 - N.N. Taleb, The black swan: The impact of the highly improbable, Random House, New York (2007).

TAngirala And Alge, 2006 - S. Tangirala and B.J. Alge, Reactions to unfair events in computer-mediated groups: A test of uncertainty management theory, $\mathrm{Or}$ ganizational Behavior and Human Decision Processes 100 (2006), pp. 1-20.

TEPPER, 2000 - B.J. Tepper, Consequences of abusive supervision, Academy of Management Journal 43 (2000), pp. 178-190.

TEPPER, 2007 - B.J. Tepper, Abusive supervision in work organizations: Review, synthesis, and research agenda, Journal of Management 33 (2007), pp. 261-289.

Tepper et AL., 2001 - B.J. Tepper, M.K. Duffy and J.D. Shaw, Personality moderators of the relationship between abusive supervision and subordinates' resistance, Journal of Applied Psychology 86 (2001), pp. 974-983.

Thau et AL., 2007 - S. Thau, K. Aquino and R. Wittek, An extension of uncertainty management theory to the self: The relationship between justice, social comparison orientation, and antisocial work behaviors, Journal of Applied Psychology 92 (2007), pp. 840-847.

TYLER, 1999 - T.R. Tyler, Why people cooperate with organizations: An identitybased perspective. In: B. Staw and R. Sutton, Editors, Research in organizational behavior Vol. 21, JAI Press, Greenwich, CT (1999), pp. 201-246.

TYLER AND BLADER, 2003 - T.R. Tyler and S.L. Blader, The group engagement model: Procedural justice, social identity, and cooperative behavior, Personality and Social Psychology Review 7 (2003), pp. 349-361.

TYLER AND LIND, 1992 - T.R. Tyler and E.A. Lind, A relational model of authority in groups. In: M. Zanna, Editor, Advances in experimental social psychology Vol. 25, Academic Press, New York (1992), pp. 115-191.

VAN DEN BOS, 2001 - K. Van den Bos, Uncertainty management: The influence of uncertainty salience on reactions to perceived procedural fairness, Journal of Personality and Social Psychology 80 (2001), pp. 931-941.

VAN DEN Bos ET AL., 2008 - K. Van den Bos, J. Ham, E.A. Lind, M. Simonis, W.J. van Essen and M. Rijpkema, Justice and the human alarm system: The impact of exclamation points and flashing lights on the justice judgment process, Journal of Experimental Social Psychology 44 (2008), pp. 201-219.

VAN DEN Bos AND Lind, 2002 - K. Van den Bos and E.A. Lind, Uncertainty management by means of fairness judgments. In: M.P. Zanna, Editor, Advances in experimental social psychology Vol. 34, Academic Press, San Diego, CA (2002), pp. 1-60.

VAN DEN Bos ET AL., 2001 - K. Van den Bos, E.A. Lind and H.A.M. Wilke, The psychology of procedural and distributive justice viewed from the perspective of fairness heuristic theory. In: R. Cropanzano, Editor, Justice in the workplace: Volume 2. From theory to practice, Erlbaum, Mahwah, NJ (2001), pp. 49-66.

Van den Bos and Miedema, 2000 - K. Van den Bos and J. Miedema, Toward understanding why fairness matters: The influence of mortality salience on reactions to procedural fairness, Journal of Personality and Social Psychology 79 (2000), pp. 355-366.

Watson ET AL., 1988 - D. Watson, L. Clark and A. Tellegen, Development and validation of brief measures of positive and negative affect, Journal of Personality and Social Psychology 54 (1988), pp. 219-235.

WEBER, 1947 - M. Weber, The theory of social and economic organization, Free Press, Glencoe, IL (1947).

Wilson ET AL., 2005 - T. Wilson, D. Centerbar, D. Kermer and D. Gilbert, The pleasures of uncertainty: Prolonging positive moods in ways people do not anticipate, Journal of Personality and Social Psychology 88 (2005), pp. 5-21.

ZelLarS ET AL., 2002 - K.L. Zellars, B.J. Tepper and M.K. Duffy, Abusive supervision and subordinates' organizational citizenship behavior, Journal of Applied Psychology 87 (2002), pp. 1068-1076.

ZOOMERANG, 2005 - Zoomerang ${ }^{\mathrm{TM}}$ (2005). Panel health: The real competitive advantage. San Francisco: Market Tools. 